\title{
How Valuable Is Financial Flexibility when Revenue Stops? Evidence from the COVID-19 Crisis
}

\author{
Rüdiger Fahlenbrach \\ Ecole Polytechnique Fédérale de Lausanne (EPFL), Swiss Finance Institute, and ECGI \\ Kevin Rageth \\ Ecole Polytechnique Fédérale de Lausanne (EPFL) \\ René M. Stulz \\ Fisher College of Business, The Ohio State University, NBER, and ECGI
}

April 2020

Revised October 12, 2020

\begin{abstract}
Firms with greater financial flexibility should be better able to fund a revenue shortfall resulting from the COVID-19 shock and benefit less from policy responses. We find that firms with high financial flexibility within an industry experience a stock price drop that is $26 \%$, or 9.7 percentage points, lower than those with low financial flexibility. This differential return persists as stock prices rebound. Firms more exposed to the COVID-19 shock benefit more from cash holdings. No evidence suggests that recent payouts worsened the average firm's drop in stock price. Our results cannot be explained by a leverage effect. (JEL G01, G14, G35, G38)
\end{abstract}

We thank Heitor Almeida, Harry DeAngelo, Dirk Jenter, Peter Limbach, Raghu Rau, Henri Servaes, and Luigi Zingales for helpful comments. We are grateful to Leandro Sanz for scientific assistance. We thank seminar participants at the joint online research seminar of the universities of Bonn, Dortmund, Wuppertal, and WHU and the University of Chicago Booth's Stigler Center online seminar. Fahlenbrach gratefully acknowledges financial support from the Swiss Finance Institute. Send correspondence to René M. Stulz, stulz.1@ osu.edu.

(C) The Author(s) 2020. Published by Oxford University Press on behalf of The Society for Financial Studies. All rights reserved. For Permissions, please e-mail: journals.permissions@oup.com. 
With the COVID-19 shock, many firms were suddenly in a position in which they could not produce and/or sell the goods and services they normally could because production and selling activities conflicted with social distancing practices. For some firms, production halted, because production would have led to workers being highly exposed to COVID-19. For other firms, customer demand flatlined, because the firm's goods and/or services entailed exposure to COVID-19. This combination of demand and supply shocks makes the COVID-19 shock unique (Baqaee and Farhi 2020). The shock led to a dramatic temporary decrease in revenues for many firms. However, firms differ in how their financial affairs are organized. Some firms hold large amounts of cash to help them cope with unexpected events. They also keep debt capacity and limit their exposure to debt rollover risk. These firms have financial flexibility, so that they can more easily fund a cash flow shortfall, such as the one created by the COVID-19 shock. In contrast, firms with less financial flexibility might rapidly descend into financial distress and be forced to take actions that healthy firms would consider detrimental to long-term shareholder wealth.

In this paper, we investigate how a firm's financial flexibility affects its stock price reaction to the COVID-19 shock. We define financial flexibility as the ease with which a firm can fund a cash flow shortfall and, therefore, expect firms with greater financial flexibility to be less affected by the shock. We consider firms to be more financially flexible if they have more cash, less short-term debt, and less longterm debt at the end of 2019.

We first analyze whether financial flexibility is valuable and if so, by how much, using firms' stock performance from February 3 to March 23, 2020, which we call the collapse period. We find evidence supportive of the role of financial flexibility in our sample, which includes all U.S. industrial firms listed on exchanges at the end of 2019. We assume that the COVID-19 shock affects firm revenue similarly within industries after accounting for firm characteristics, so that our results account for industry differences. When we compare highly financially flexible firms to firms with low flexibility, we find that the stock price of highly flexible firms fell by $26 \%$ less than the stock price of firms with low flexibility during the collapse period. We expect that more financially flexible firms benefit less from the positive news about the stimulus package announced on March 23, 2020, that affected stock prices on March 24, 2020, a day we call stimulus 
day. On stimulus day, firms with less debt experience lower stock returns, but the other attributes of financial flexibility are not related to stock returns. We also find that the worse performance of firms with lower financial flexibility compared to their industry persists through the rebound of the stock market.

Since the COVID-19 shock has a greater and more direct impact on the revenues of firms that have greater exposure to COVID-19 because of how they produce or how they sell, we expect firms to benefit more from financial flexibility if they are more exposed to the shock. We use several different fundamental approaches to measure a firm's exposure to the shock. These approaches include the estimates of Koren and Peto (2020), who classify industries based on how they are affected by social distancing. We also allow for the impact of affected industries on upstream industries that may not be industries exposed to the need for social distancing but are affected because they sell to industries that are exposed. Through manual review of six-digit NAICS industry descriptions, we attempt to eliminate those industries where selling takes place online rather than in-person. We find that when we classify industries as highly affected by the shock because of their sensitivity to the need for social distancing either directly or indirectly as suppliers to such industries, firms in these industries benefitted more from higher cash holdings. The additional economic impact of cash holdings on the stock price drop of firms highly exposed to COVID-19 is large. Compared to a firm that is not highly exposed to COVID-19, a firm that is highly exposed and has cash at the 75th percentile of the distribution of cash holdings experiences a stock price drop that is 7.3 percentage points lower than a firm that has cash at the 25 th percentile of the distribution of cash holdings.

Firms with greater financial flexibility also performed better during the post-Lehman stock market drop in 2008-2009. We find that the coefficients for long-term debt and on cash holdings in our regressions explaining stock returns following the Lehman bankruptcy are remarkably similar to the coefficients for these variables in our regressions explaining stock returns during the COVID-19 shock. This suggests that for the sample as a whole the value of financial flexibility is similar across the two crises. However, we show that the industries that perform worst in 2008-2009 and the ones that perform worst in 2020 differ. The industries that perform worst during the collapse period in 2020 have a much higher exposure to the need for social distancing than the industries that have the worst performance in 2008-2009. Perhaps more 
importantly, the differential impact of cash holdings we document for firms exposed to the need for social distancing is unique to the COVID-19 shock and is economically large.

It is well-known since Modigliani and Miller (1958) that the equity of a levered firm is riskier than the equity of an otherwise identical firm with less leverage. Hamada (1972) and Galai and Masulis (1976) show that, theoretically, firms with more leverage have a higher exposure to market movements when the leverage irrelevance of Modigliani and Miller (1958) holds. With Merton (1974), the value of equity falls proportionately more when the firm's leverage is higher for a given fall in the value of the firm's assets. Hence, it is important to ascertain that the greater stock return drop of firms with lower financial flexibility is not simply the mechanical result of these firms having more leverage. Three facts show that the effect we document can reasonably be attributed to financial flexibility. First, the mechanical leverage effect indicates that low financial flexibility firms should perform better than high financial flexibility firms when stock prices rebound. This is not the case. Second, we find that the benefit of financial flexibility that is unique to firms highly affected by COVID-19 is due to cash holdings only when the leverage effect implies that the benefit of financial flexibility should hold for leverage as well. Third, though the market decreases sharply during the collapse period, volatility increases sharply as well. The increase in volatility mitigates the leverage effect because the equity of a levered firm can be modeled as a call option (Merton 1974). We show that the magnitude of the volatility effect is large enough that it can completely offset the leverage effect in a calibration of Merton (1974).

Because investment programs tend to be sticky, financial flexibility could be more valuable for firms with high capital expenditures and high R\&D expenditures. The relation between stock returns and capital expenditures is sensitive to the specification. We see no evidence that firms with larger R\&D expenditures experience a larger stock-price drop. Firms with more variable costs should be affected less by a temporary revenue shortfall because they can scale down their operations more easily. We find some evidence that firms for which, everything else equal, costs of goods sold (COGS), a measure of variable costs, are more important are affected less. In contrast, firms with more selling, general, and administrative (SG\&A) expenses, a measure more dependent on fixed costs, are affected more. For given financial flexibility, 
corporate diversification could help firms cope better with an adverse shock if a conglomerate is active both in industries highly affected by the shock and in industries less affected by the shock. We find some evidence that such conglomerates performed better than stand-alone highly affected firms during the collapse period.

A way for firms to increase financial flexibility is through greater retention of cash flow (see, e.g., DeAngelo, Gonçalves, and Stulz 2018). The CARES Act limits repurchases by corporations. In the public debate about the act, there was much discussion that corporations would have been more resilient had they received lower payouts in previous years (Schlesinger 2020). Many observers have expressed concerns that large payouts handicap firms, whose balance sheets, upon a large payout, insufficiently cushion firms against adverse events. As John Plender (2020) put it in Financial Times, "woe betide anyone who is going into this virus-induced global recession with an efficient balance sheet." Logically, if firms had lower payouts in the past, they would have been more financially flexible. Surprisingly, there is no statistically significant relation between past payouts and stock returns during the collapse period whether or not we control for our financial flexibility proxies. We provide a straightforward explanation for this surprising result. If firms had not made payouts in 2019 and had instead increased their cash holdings or decreased long-term debt, the impact for the average firm would have been small. We find similar results when we use the cumulative payouts over the last 3 years instead of the payouts in 2019. However, the payout policy of firms with high cumulative payouts over assets for the 3 years ending in 2019 has a substantial impact on their financial flexibility on average. If these firms had not had dividends and repurchases, they could have bought back all their long-term debt.

Many studies explore whether financial constraints have real effects on firms. ${ }^{1}$ An obvious question is whether, with our proxies for financial flexibility, we are proxying for whether a firm is free from financial constraints. In principle, a highly financially constrained firm would be one with little flexibility. We

\footnotetext{
${ }^{1}$ For example, one of the most cited studies of the impact of the GFC on firms investigates how the crisis affected the extent to which firms were financially constrained and how financial constraints led firms to cut back on their spending plans (Campello, Graham, and Harvey 2010).
} 
investigate whether firms judged to be more financially constrained according to the well-known indexes of Kaplan and Zingales (1997), Whited and Wu (2006), and Hadlock and Pierce (2010) have worse stock returns during the collapse period. We find no evidence that they do. Consequently, measures of financial constraints used in the literature do not appear to be good proxies for lack of financial flexibility. A possible explanation is that a firm that cannot access outside finance (and is thus financially constrained) may have accumulated large holdings of cash internally to cope with unexpected shocks (Almeida, Campello, and Weisbach 2004; Opler et al. 1999). Hence, such a firm may be better able to cope with a cash flow shock than a firm that has access to financial markets but has low cash holdings and is highly levered. Interestingly, a measure developed by Huang and Ritter (2020) of how much a firm would need to access outside funding if it spent as much as in the previous year has explanatory power in our tests. We show that firms that would run out of cash without accessing outside funding are more affected by the shock. Similarly, Hoberg and Maksimovic (2015) use the management discussion and analysis section of firms' form $10-$ Ks to develop a measure of financial constraints due to broad liquidity challenges leading to potential underinvestment. We find that firms that face these liquidity challenges are more affected by the shock.

Three important caveats for our study are in order. First, we focus on how markets react to news about the COVID-19 shock and how that reaction varies across firms that differ in financial flexibility. Markets make mistakes. They can be inefficient. They can overreact and underreact. Firm-level idiosyncratic mistakes make it more difficult for us to find evidence of a role for financial flexibility. Second, financial flexibility comes with costs. For instance, as shown in Jensen (1986) and Stulz (1990), agency costs can be higher for firms with greater financial flexibility. We do not address these costs in our study. Third, we ignore general equilibrium effects. For instance, when we make a statement about how stock returns of firms would have been affected had these firms not made payouts for the last 3 years, we ignore that the market's stock price drop would have been different as a result.

Our paper contributes to several literatures. First, we add to the literature on the benefits and costs of financial flexibility. As pointed out by Denis (2011, p. 667), this "literature encompasses studies of the 
determinants and consequences of corporate cash holdings, as well as the impact of flexibility considerations on corporate capital structure and payout policies." Graham and Harvey (2001) find that financial flexibility is the single most important determinant of capital structure for CFOs. DeAngelo and DeAngelo (2007) show that when financial flexibility is valuable, ex ante low leverage is optimal because it gives firms the option to lever up later when they have to do so. Our paper provides evidence on the value of flexibility when a firm is affected by a large and unexpected revenue shock, which is the type of situation for which firms have precautionary cash holdings and keep financial flexibility.

Second, the paper contributes to the literature on how corporate balance sheets affect the transmission of shocks. A vast literature in macroeconomics building on Bernanke and Gertler (1989) shows how the impact of shocks is magnified for firms with weaker balance sheets. The finance literature has shown that firms with weaker balance sheets at the start of the global financial crisis (GFC) were affected more by the crisis (Kahle and Stulz 2013) and that firm balance sheets were important in the propagation of the GFC (Giroud and Mueller 2017). In this literature, it is typically difficult to find a shock that is fully unanticipated. As a result, a firm's finances may be organized in a way that the firm finds optimal to deal with a partially anticipated shock. This issue does not arise here. There is no reason to believe that the balance sheets and income statements of firms at the end of fiscal year 2019 were in any way affected by anticipations of a risk of a COVID-19 crisis.

Third, we contribute to the crisis literature. A large literature examines the impact of the GFC on firms (see, e.g., Almeida et al. 2011; Campello, Graham, and Harvey 2010; Chodorow-Reich 2014; Duchin, Ozbas, and Sensoy 2010; Giroud and Mueller 2017; Ivashina and Scharfstein 2010; Kahle and Stulz 2013). Much of that literature focuses on how the impact of the GFC on the ability of financial intermediaries to perform their function influenced firms, but some studies show that the strength of firms' balance sheet mediates the impact of the GFC. However, the COVID-19 crisis differs in many ways from the GFC, and, hence, studying how balance sheets affect the reaction of stock prices to the COVID-19 shock is helpful to better understand the role of firm balance sheets during crises. Though September 2008 and March 2020 look similar, in that they involve a rapid collapse in stock prices and unprecedented interventions by the 
Federal Reserve, the most dramatic period of the GFC originated in the financial sector with the collapse of Lehman. In contrast, the COVID-19 shock originated as a public health crisis; it did not originate inside the financial sector.

Contemporaneous work on firms and the COVID-19 crisis includes Ramelli and Wagner (2020), who examine stock-price reactions of U.S. firms to the COVID-19 crisis since January 2020, with a focus on their international and China exposure, but they also show a negative relation between stock returns and leverage and a positive relation between cash and stock returns. Albuquerque et al. (2020) use U.S. data to show that firms with high environmental and social ratings had better returns during the first quarter of 2020, even after controlling for cash (positive effect on returns) and leverage (negative effect on returns). De Vito and Gómez (2020) use an international sample and simulations to analyze how much time firms with limited operating flexibility would have before they exhaust cash reserves. Using a large international sample, Ding et al. (2020) examine the connection between stronger pre-2020 finances, less exposure to COVID-19 through global supply chains, more CSR activities, and better corporate governance and the stock price reactions to COVID-19 cases. Pagano, Wagner, and Zechner (2020) show that firms whose operations are more resilient to the need for social distancing experienced a lower drop in their stock price. Similarly, Papanikolaou and Schmidt (2020) find that sectors in which a higher fraction of the workforce is not able to work remotely experienced significantly greater declines in employment and stock returns. Acharya and Steffen (2020) examine credit line drawdowns and security issuance of U.S. corporations during the COVID-19 pandemic. Li, Strahan, and Zhang (2020) document how banks dealt with the withdrawal of funds from preexisting credit lines. In contrast to these studies, our focus is on evaluating existing finance theories concerning the role of financial flexibility, in assessing the importance of financial flexibility in mitigating the impact of the shock for all firms as well as for firms with greater fundamental exposure to the shock, and in evaluating how flexibility would have been different had firms had lower payouts. $^{2}$

\footnotetext{
${ }^{2}$ Other work includes Loughran and McDonald (2020), who examine risk disclosures of companies and find that $79 \%$ of companies had no pandemic risk disclosure in 2018. Hassan et al. (2020) use text-based measures of the
} 


\section{Financial Economics and Sudden Temporary Revenue Stops}

In this section, we make predictions about the impact of a sudden temporary revenue stop, using the existing financial economics literature. We investigate our predictions empirically in the subsequent sections. We start with two extreme benchmarks. The first one is the traditional perfect markets benchmark and the second is the case of binding financial constraints. We then address scenarios where a firm's financial situation is between these two extreme benchmarks.

\subsection{Perfect markets: All-equity firm}

Consider the simplest case of perfect markets where a firm earns every month revenue $R_{t}$ and incurs costs $C_{t}$, so that its net operating cash flow $C F_{t}$ is equal to $R_{t}-C_{t}$. The total cash flow of the firm is $C F_{t}-$ $I_{t}$, where $I_{t}$ are investment expenses. For now, we assume that the costs are fixed, so that the firm still has to pay them if production stops. To simplify the discussion, we also assume that the firm has no investment expenses. Let $S_{t}$ be the value of the firm at time $t$. Assume that time $t$ cash flows are discounted to today using the discount factor $D(t)$. With these assumptions, we have the following expression for the value $S_{0}$ of an all-equity firm: ${ }^{3}$

$$
S_{0}=\sum_{t=1}^{\infty} D(t) E_{0}\left(R_{t}-C_{t}\right),
$$

where $E_{0}(\ldots)$ is the expectation operator.

Suppose now that the firm learns that its revenue will fall to zero for $n$ months and then will resume at the level expected at time zero. For now, we assume that the discount factors are unchanged. In this case, using a superscript STOP to denote the value of the equity with a sudden temporary stop in revenue, the value of equity becomes

$$
S_{0}^{\mathrm{STOP}}=\sum_{t=1}^{n} D(t) E_{0}\left(-C_{t}\right)+\sum_{t=n+1}^{\infty} D(t) E_{0}\left(R_{t}-C_{t}\right) .
$$

costs and benefits associated with the spread of COVID-19 and find that most firms are concerned with a sudden drop in demand and disrupted supply chains, but not with financial constraints. Eldar and Wittry (2020) show that a surprising number of firms adopt poison pills during the crisis.

${ }^{3}$ Equation (1) is simply equation 2.20 of Fama and Miller (1972) with the assumptions we have made. 
With this scenario, the loss from the sudden stop is the cumulative loss in revenue. If the firm's costs are unaffected, the firm still has to pay its costs for $n$ months without receiving any revenue. In this simple setup, the value of the equity falls by the cumulative loss of expected revenue over $n$ months. With perfect markets, the firm can borrow against future income to pay its costs as long as the present value of future cash flows exceeds the present value of the costs it has to pay during the $n$ months. The collateral for its borrowing is the value of the firm after the end of the momentary revenue stop. If the present value of the costs to be paid over $n$ months exceeds the present value of the cash flows after the end of the $n$ months, the firm has no value and liquidates. Therefore, the loss in equity value assuming the firm has value after the shock is

$$
S_{0}-S_{0}^{\mathrm{STOP}}=\sum_{t=1}^{n} D(t) E_{0}\left(R_{t}\right)
$$

Whether or not equity is wiped out depends on the length of the sudden stop as well as the profitability of the firm. To see this, note that the firm has to finance the costs it still incurs. For given revenue, the lower the costs, the less the firm has to finance. Further, for given revenue, the value of the firm after the end of the sudden shock is negatively related to costs, so that the lower the costs, the greater the collateral against which to borrow.

Note that firm value after the end of the sudden stop could be lower for at least two additional reasons. First, the event that causes the sudden stop could also affect the discount factors. In a crisis period, the riskfree rate can fall as investors become more risk averse and the firm's risk premium, measured as the difference between the firm's expected stock return and the risk-free rate, can increase. If the risk premium increases sufficiently, the firm experiences an increase in discount rates, and it becomes more likely that the firm will be liquidated as the present value of the cash flows it will receive after the $n$ months of no revenue is lower. Second, we assume that the firm's cash flows after $n$ months are the same as what they would have been absent the shock. If that is not the case and the cash flows are lower for some period of time, the present value of the firm after the end of the sudden revenue stop is lower and the firm is again more likely to be liquidated. 
So far, we have assumed that all the costs are fixed. When its revenue disappears, the firm still has to pay all its costs, so that the cost of the shock is the present value of the disappeared revenue. Obviously, in general, firms have variable costs in addition to their fixed costs. If the firm does not produce for some period of time, it can save the variable costs. Consider the extreme case where all costs are variable, so that if the firm does not produce it does not incur any costs. Such a firm has low operating leverage. In this case, the firm just loses its discounted expected net cash flow over $n$ months, and its value with the shock is

$$
S_{0}^{\mathrm{STOP}}=\sum_{t=n+1}^{\infty} D(t) E_{0}\left(R_{t}-C_{t}\right)
$$

With only variable costs, the all-equity firm would never go out of business because of a temporary sudden stop. The firm would go to sleep and wake up $n$ months from now.

In general, a firm has some costs it has to pay even if it does not produce. In this case, the extent of the loss from the sudden stop depends on the firm's ability to reduce its costs while it is not producing. With decreasing operating leverage, the firm moves from Equation (2) toward Equation (4). The less operating leverage it has, the less it loses from the sudden shock.

We assume in the analysis that during the sudden stop the revenue falls to zero. We do so for simplicity. Allowing revenue to fall only partially leads to the possibility that revenue falls so little that the firm is still profitable during the stop. In that case, the firm never liquidates. If revenue falls so that the firm is not profitable during the stop, the analysis is the same as if revenue goes to zero.

\subsection{Perfect markets: Levered firm}

Suppose now the firm has debt. For simplicity, assume that the firm owes a constant debt payment each month forever. With perfect markets, these debt payments simply correspond to an increase in costs. Equations (1) through (4) are still correct for the value of equity as long as that value is positive. Greater debt payments mean that the loss to equity from the shock is higher because, everything else equal, the firm's fixed costs are higher. Greater debt payments also imply that it is more likely that the firm liquidates because the firm has less collateral (in this case, the value of the firm once the temporary drop in revenue is over) it can use to borrow against to fund its costs. If we compare two identical firms except one has debt 
and the other does not, the value of the equity of the firm with debt falls proportionately more in response to the shock.

Lastly, we can distinguish between short-term debt and long-term debt. For simplicity, assume that short-term debt is debt with payments only during the sudden stop and long-term debt is debt with payments only after the sudden stop. With our assumption of perfect markets, provided that the present value of the debt payments is the same, it does not matter whether the debt is short-term or long-term as long as the firm is solvent. If the debt is only short-term, the firm has to borrow more to fund the cash flow shortfall, but since it does not have long-term debt the value of the collateral that it can use to borrow against is higher. Alternatively, if the debt is only long-term, the firm borrows less because its costs during the sudden stop are lower but it has less collateral to borrow against because its costs after the sudden stop are higher.

\subsection{The case of a financially constrained firm}

Consider now a firm that is financially constrained in that it cannot raise outside finance. Nothing else changes from the earlier discussion in Sections 1.1 and 1.2, which makes the existence of financial constraints somewhat arbitrary. In general, financial constraints arise from frictions that make markets imperfect. To keep the analysis simple and to show starkly the implications of a sudden temporary revenue stop for a firm that cannot access outside funding, we do not model the frictions that cause the firm to be financially constrained.

In the financially constrained firm case, a firm that does not have financial resources to fund its costs has to liquidate even if that firm is still highly valuable unless it can sell assets. It is well-known that selling assets can provide firms with funding (see, e.g., Shleifer and Vishny 1992), but it is also well-known that during a crisis selling assets may entail fire sale discounts (see, e.g., Shleifer and Vishny 2011) and hence, if feasible, is an expensive form of funding. With the simple firm we consider, shareholders could sell a fraction of the firm large enough to fund the cash flow shortfall. With perfect markets, there would be no

fire sale discount. With market imperfections, such a discount would be likely, so that the cost to the shareholders would increase by the fire sale discount. 
A firm that is financially constrained would not put itself in a position where a revenue shortfall that leaves the firm valuable absent financial constraints either puts it out of business or forces it to sell assets. Generally, firms that are financially constrained invest in cash holdings so that they have a cash buffer if they face a shortfall in revenues (Almeida, Campello, and Weisbach 2004). Consider a financially constrained firm with fixed costs and a fixed cash buffer. Further, assume that the firm cannot liquidate to avoid paying fixed costs and cannot sell assets. In this case, if the buffer is large enough to enable the firm to not fail during the $n$ months it cannot produce, the firm will use the cash buffer to pay its costs. If the buffer is not large enough and the firm cannot sell assets, the firm has to liquidate during the period without revenue. With enough uncertainty, the firm would wait to liquidate until it has exhausted its cash buffer as it would be possible that things could improve enough to avoid liquidation.

It follows from our analysis that, for a financially constrained firm, the size of the cash buffer is crucial. A buffer that is too low forces the firm to sell assets or liquidate. It could also force the firm to attempt to reduce costs in ways that are inefficient. For instance, the firm might stop investments that are worthwhile, or reduce maintenance expenses.

\subsection{Between the benchmarks}

The typical firm is one that faces frictions in raising funds, but is not in a situation in which it cannot raise funds. As a result, external finance is costly for such a firm and it becomes more costly as it has less collateral to make available to raise outside funds (see, e.g., Fazzari, Hubbard, and Petersen 1988). Agency costs and information asymmetries are reasons why outside finance is costly and these costs increase as firms become more highly levered. For such a firm, cash will be a cheaper source of funding than external funding. The firm will also have cheaper funding if it has more collateral available to raise funds. If the firm is diversified, the availability of an internal capital market means that it can fund some activities without having to resort to external funding, so that the internal capital market of a diversified firm can mitigate the impact of the sudden revenue stop.

A typical firm will have access to outside funding, so that it will resort to asset sales only in extreme cases. Such a firm is negatively affected if outside funding becomes more costly and/or difficult. The extent 
to which it is affected depends in part on how urgent its need for funding is. A firm that is financially flexible has ample cash holdings, so that it can wait to raise funds externally. It can avoid having to raise external finance when markets are stressed. It also will be in a position where it has debt capacity so that it can raise external funds easily and at a low cost.

\subsection{Hypotheses}

We derive the following testable hypotheses from our analysis in Sections 1.1 to 1.4:

Hypothesis 1. Financial flexibility and equity value. Stock prices fall when the market learns about a temporary sudden revenue stop. The greater the financial flexibility of a firm, everything else equal, the smaller the stock price drop. Financial flexibility is especially important for industries most affected by the COVID-19 shock since these firms are expected to have a larger drop in revenue. Given financial flexibility, the stock-price drop is less for firms that are better able to cut costs. The value of financial flexibility is higher when the financial system is more stressed. Everything else equal, measures that reduce the stress in the financial system benefit firms with low financial flexibility more.

Easier access to outside finance should make it easier for a firm to finance its cash flow shortfall if there were a temporary sudden stop of revenue. In this case, the following result holds:

Hypothesis 2. Financial constraints. More financially constrained firms experience worse equity returns in response to a temporary sudden revenue stop.

\section{Data and Sample Summary Statistics}

In this section, we describe how we construct our sample, the characteristics of sample firms, and the performance of firms during our sample period. In Section 4, we introduce measures of fundamental exposure to the COVID-19 shock and postpone discussion of these measures to that section.

We focus on firms for which 2019 fiscal year-end data are available from Compustat at the time of writing. We drop financial firms, utilities, not-for-profit and governmental firms, and firms with non-U.S. headquarters. We obtain stock market data from Compustat's CapitalIQ North America Daily database. We remove stocks with average prices of less than $\$ 1$, and those with a security type not equal to "common, 
ordinary." After these additional filters, our final sample consists of 1,857 firms. Appendix A offers details about the sample selection process and on how many firms we drop due to each filter. We use the 1-month Treasury-bill rate from the St. Louis Federal Reserve. To classify firms as conglomerates, we use the Compustat Segments database.

We consider firms to be more financially flexible if they hold more cash, have less short-term debt, and have less long-term debt. ${ }^{4}$ Table 1 shows that the average firm has cash over assets of $22.4 \%$. Median cash over assets is $11.2 \%$. The difference between the mean and the median of cash over assets is not surprising as the distribution of cash holdings is skewed. The typical firm has little short-term debt, where short-term debt is defined as debt that matures within 2020, as the median short-term debt over assets is only $1.3 \%$. We compute net short-term debt, which is short-term debt in excess of cash. Both median and mean net short-term debt over assets are negative, so that the median and the average firm hold more cash than shortterm debt. Long-term debt is much more substantial as mean long-term debt over assets is $27.9 \%$ and median long-term debt over assets is $25.9 \%$. The average payout ratio, defined as dividends plus repurchases over assets, is 0.035 . As a comparison, Kahle and Stulz (2020) calculate an average net payout over assets ratio of 0.048 for U.S. firms between 2010 and 2017.

We later investigate whether measures of financial constraints commonly used in the literature are helpful to explain how stock returns respond to the shock. We use five different measures. Three of these measures use coefficients from regressions that predict whether a firm is financially constrained. The first of these measures is the Kaplan and Zingales (1997) measure (KZ index). We follow Lamont, Polk, and Saá-Requejo (2001) in the construction of the index. A higher value of this measure means that a firm is more constrained. With that index, a firm is more constrained if it has lower cash flow, a higher Tobin's q, more leverage, less dividends, and less cash. The second measure is the Whited and Wu (2006) index (WW index). With that index, a firm is more financially constrained if its cash flow is lower, if it does not pay

\footnotetext{
${ }^{4}$ Acharya and Steffen (2020) analyze an additional measure of financial flexibility, undrawn credit lines, and show that the stock market did not value them until after the Fed intervention on March 23. We confirm their results in additional robustness tests we discuss below.
} 
dividends, if it has more leverage, if it has less assets, if its industry grows faster, and if it grows more slowly. Note that cash does not enter the index. The last index we consider is the Size-Age (SA) index of Hadlock and Pierce (2010) that depends only on firm size and firm age. With that index, older firms and larger firms are less constrained. For each of these three indexes, we define a firm as financially constrained if it is in the top quartile of the distribution of the relevant index. Hoberg and Maksimovic (2015) describe that an issue with measures of financial constraints, such as the KZ and WW indexes, is that they rely on reduced-form predictive models estimated on small samples, which are then applied out of sample to materially different populations of firms. Hoberg and Maksimovic (2015) therefore develop alternative measures of financial constraints based on an analysis of the Management's Discussion and Analysis (MD\&A) section in 10-Ks. We use their overall measure of financial constraints due to broad liquidity challenges leading to potential underinvestment as our fourth measure of financial constraints. We define a firm as financially constrained if it is in the top quartile of the distribution of the Hoberg and Maksimovic (2015) overall measure (HM measure from now on). ${ }^{5}$

Huang and Ritter (2020) construct a measure, cash $_{\text {ex ante, }}$ which predicts the end-of-year cash position of a firm if the firm does not access external financing during the year. It is defined as the cash position at the end of the last fiscal year, plus the net cash flow of last year, used as a projection for the current year's net cash flow. ${ }^{6}$ Huang and Ritter (2020) show that $27.9 \%$ of all firms are projected to have a financing deficit without raising additional financing that year. We use the projected cash-deficit based on the Huang

\footnotetext{
${ }^{5}$ A potential limitation of using the Hoberg and Maksimovic (2015) measure in our sample is that the last available data year is 2015. Hoberg and Maksimovic (2015, p. 1326) caution in their paper that their constraints variables have autocorrelation coefficients that range from 0.4 to 0.6 , and that a firm that is constrained in a given year is quite likely to be constrained the next year, but is unlikely to be still constrained 2 to 3 years later. We create a correlation table for the time-series correlation of the HM measure for all available years. The autocorrelations during the original sample period (1997-2009) of Hoberg and Maksimovic (2015) are smaller than in the later years. The HM index of 2015 is highly correlated with the HM index of 2011 (0.68). We therefore believe that it is justifiable to use the HM financial constraints measure end of 2015 as a proxy for financial constraints end of 2019. Data are available for approximately half of all sample firms, because not all firms discuss their liquidity situation in their 10K.

${ }^{6}$ More precisely, net cash flow is defined as the difference between the internal cash flow and the sum of investment, change in noncash net working capital, and dividends.
} 
and Ritter's (2020) cash $_{\mathrm{ex}}$ ante measure as our final measure of whether a firm is financially constrained. In our sample, $20.1 \%$ of firms are projected to have negative cash absent external financing.

Table 1 also shows the stock returns of the firms in our sample for the collapse period from February 2 to March 23, 2020. We compute daily excess returns, which we define as the log of one plus the total return on a stock minus the risk-free rate defined as the 1-month daily Treasury-bill rate. We cumulate these returns over the collapse period. It is not surprising that the cumulative returns are negative and large in absolute value. For the whole sample, we have an average cumulative daily log return of $-37.8 \%$ and a median cumulative daily $\log$ return of $-38.7 \%$. As a comparison, the log return to the S\&P 500 from February 3 to March 23 is $-37.3 \%(\ln (2237.40 / 3248.92))$. Almost all stocks have a negative cumulative $\log$ return, as the $95^{\text {th }}$ percentile of the distribution is $-5.5 \%$. However, the range of the cumulative excess returns is broad as the $5^{\text {th }}$ percentile is $-71.2 \%$ and the standard deviation of the cumulative excess return is $26.0 \%$.

Next, we turn to the stock performance of our sample firms on stimulus day, March 24, 2020. On that day, the average sample firm experiences an excess stock return of $9.2 \%$. The median stock return is $8.7 \%$. Most firms have a positive excess return on that day, as the $5^{\text {th }}$ percentile is only a small negative return of $-1.9 \%$.

Table 2 shows correlations among the variables we use in our regressions. The correlations among the variables we use as proxies for financial flexibility are low. The highest are between long-term debt measures and cash. Firms that have high levels of long-term debt over assets have lower cash holdings. Not surprisingly, in light of the literature on cash holdings (see, e.g., Opler et al. 1999), we find that cash holdings have high correlations with R\&D expenses and SG\&A expenses. Short-term debt and long-term debt do not have noticeably high correlations with any firm characteristic. The correlations between the various financial constraints indexes show little overlap between the firms classified as financially constrained with the KZ index and the ones classified with the other indexes. The correlations are larger between the WW index and the SA index. All indexes have very low correlations with the HR measure and the HM measure. 


\section{Financial Flexibility and the Cross-Section of Stock Returns}

In this section, we investigate whether the cross-sectional variation in stock returns during the COVID19 collapse period and on stimulus day can be partially explained by our financial flexibility hypothesis for equity (hypothesis 1 of Section 1.5). Further, we attempt to measure the value of financial flexibility during the collapse period, defined as the difference in cumulative excess returns between firms with high financial flexibility and firms with low financial flexibility. We also compare the relation between stock returns and financial flexibility during the COVID-19 collapse period to the period following the bankruptcy of Lehman in 2008. Lastly, we show that the differential performance related to financial flexibility does not disappear with the rebound in stock prices.

\subsection{Financial flexibility and the COVID-19 collapse period}

Table 3 presents estimates of regressions of stock returns on our proxies for financial flexibility, which are cash to assets, short-term debt to assets, and long-term debt to assets. To control for industry differences, we add industry fixed effects, based on the Fama-French 49 industry definitions. To account for variation in asset returns explained by the asset pricing literature, we control for firm characteristics known to be related to stock returns. ${ }^{7}$ Specifically, we control for characteristics that correspond to the risk factors used in several well-known studies. We control for equity beta, book-to-market, and firm size (see, e.g., Fama and French 1993), momentum (see, e.g., Carhart 1997), and profitability (see, e.g., Fama and French 2015; Novy-Marx 2013). To account for the ease with which a firm can cut costs, we control for capital expenditures, R\&D, COGS, and SG\&A. We expect firms that have more capital expenditures, more R\&D, or more SG\&A to find it more difficult to cut spending. From our discussion in Section 1, these firms should be affected more by the shock. To the extent that cost of goods sold (COGS) measures variable costs, firms with higher COGS, everything else constant, should have a lower stock-price drop. Finally, we use an indicator variable for an investment-grade rating and for a high-yield rating to account for information

\footnotetext{
${ }^{7}$ We adapt the approach of Fahlenbrach, Prilmeier, and Stulz (2012), who examine the determinants of bank stock returns during the GFC.
} 
ratings might have about financial flexibility that is not captured by our proxies for financial flexibility. We also include the payout ratio in all regressions.

The regression reported in column 1 of Table 3 includes our three proxies for financial flexibility as well as the additional variables just discussed. We find that each proxy for flexibility has a significant coefficient with the expected sign for the collapse period. The economic effects are meaningful. A onestandard-deviation lower cash, higher short-term debt, and higher long-term debt are associated with collapse period returns that are $3.5 \%, 1.3 \%$, and $3.7 \%$ lower, respectively. Having an investment-grade rating adds no information. Neither capital expenditures nor R\&D expenditures has a significant coefficient. However, as expected, SG\&A has a negative and significant coefficient and COGS over sales has a positive significant coefficient. The payout ratio does not have a significant coefficient. Column 2 reports the same regression but for stimulus day. Of the flexibility variables, only long-term debt has a significant positive coefficient. Among the other variables (other than the characteristics from the asset pricing literature), only SG\&A has a significant coefficient.

When we consider the coefficients for the characteristics, we find that the coefficient for equity beta is significantly negative during the collapse period and significantly positive on stimulus day. Larger firms perform better during the collapse period and on stimulus day. High book-to-market firms perform better during the collapse period, but book-to-market does not explain variation in returns on stimulus day. Neither profitability nor momentum helps explain the cross-sectional variation in returns during the collapse period. Of profitability and momentum, only momentum is significant with a positive coefficient for stimulus day.

In columns 3 and 4 of Table 3, we replace cash over assets and short-term debt over assets with net short-term debt over assets and add an indicator variable that takes a value of one if a firm has a high-yield rating. The coefficient for net short-term debt is negative and significant as expected. The high-yield debt rating indicator variable has a negative and statistically significant coefficient. The coefficient is also economically significant. Companies that have a non-investment-grade rating have 5.7 percentage point lower returns during the collapse period even though we control for our flexibility proxies. The magnitude of the coefficient for long-term debt in column 3 is weaker than in the other comparable regressions. In 
column 4, which reports estimates for stimulus day, the coefficient for long-term debt is not significant but the coefficient for the high-yield indicator variable is positive and significant. The stock price of noninvestment-grade-rated companies increases by an additional 1.6 percentage points on stimulus day. No other changes are noticeable. Columns 5 and 6 use total book debt over assets instead of short-term debt over assets and long-term debt over assets. The coefficients for total book debt are significant and of the expected sign. Nothing else changes.

We conduct several robustness tests that we do not report in a table. First, we use the average payout ratio over 3 years ending in 2019 instead of the payout ratio in 2019. Our results for the financial flexibility variables are unchanged and the coefficient for the average payout ratio remains indistinguishable from zero. Second, instead of calculating the payout ratio as payouts over assets, we calculate it as payouts over net income minus extraordinary items. With this definition, the payout ratio is not meaningful if the denominator is negative. We therefore drop observations with negative net income minus extraordinary items. Using this definition does not change our conclusion about the value of financial flexibility or the relation between payouts and returns. Third, we also estimate the regressions in columns 1 and 2 replacing capital expenditures with plant, property, and equipment (PPE) over assets. The coefficient for PPE is not significant, and our conclusions are unchanged. Fourth, we also include unused credit lines over total assets at the end of fiscal year 2019 as an additional measure of financial flexibility in the regressions. Acharya and Steffen (2020) show that especially BBB-rated companies quickly drew down their credit lines in March and April 2020 to secure financing. We obtain the size of unused credit lines from CapitalIQ. The data are available for about two-thirds of our sample. The coefficient for unused credit lines is statistically indistinguishable from zero in regressions similar to those of columns 1 and 2 of Table 3 , and the results on our financial flexibility variables remain quantitatively and qualitatively the same. ${ }^{8}$

\footnotetext{
${ }^{8}$ We do not include unused credit lines as one of our main measures of financial flexibility in the entire analysis because we lose approximately one-third of our sample due to the unavailability of credit line usage data. Acharya and Steffen (2020) report a similar nonresult in their Table 7, panel B, column 1. They show that unused credit lines have a positive effect on stock returns only after the stimulus measures of the Fed and Congress passed on March 23.
} 
Our main results on the importance of cash and long-term debt are statistically and economically very robust to either winsorizing or truncating the data at the 1st or 99th percentile. One also may be concerned about dependence among the error terms. When we cluster standard errors at the Fama-French 49 industry level, the statistical significance of the financial flexibility indicator variables cash and long-term debt decreases only slightly relative to the base case of ordinary least squares (OLS) standard errors. The economically weaker short-term debt coefficients cease to be statistically significant. Finally, we also estimate regressions in which we adjust the cumulative stock returns using a four-factor (market, book-tomarket, size, and momentum) model. ${ }^{9}$ The coefficients for the financial flexibility variables all remain economically large and statistically significant.

What can we say about the value of financial flexibility during the COVID-19 crisis? One way to assess that value is to compare a firm that has low financial flexibility versus one that has high financial flexibility. Suppose that the low financial flexibility firm is at the 25 th percentile of cash holdings, at the 75 th percentile of short-term debt, and at the 75th percentile of long-term debt. Compare that firm to a firm with high financial flexibility that is at the 75th percentile of cash holdings, at the 25th percentile of short-term debt, and at the 25 th percentile of long-term debt. The difference in cumulative excess returns between these two firms using the regression coefficients in column 1 of Table 3 is 9.7 percentage points during the collapse period when the mean decrease in the value of common stock across firms is 37.8 percentage points. Another way to put this is that a firm with high financial flexibility experienced a drop in its stock price $26 \%$ smaller than the average firm. Similar calculations for column 3 (net short-term debt instead of cash and short-term debt) yield an 8.0 percentage point difference (21\% smaller drop than the average). For column 5, where we have cash and total debt, the calculations yield a 9.5 percentage point difference $(25 \%$ smaller drop).

\footnotetext{
${ }^{9}$ We estimate factor loadings using regressions of daily stock prices on the factors (downloaded from Kenneth French's website at https://mba.tuck.dartmouth.edu/pages/faculty/ken.french/data_library.html) during 2017-2019. We calculate an abnormal return for each day during our sample period by subtracting the estimated factor loading multiplied by the factor realization on the respective day. Finally, we winsorize the cumulative abnormal return from February 2 to March 23, 2020, at the 1st and 99th percentiles.
} 


\subsection{Financial flexibility and the global financial crisis}

Columns 7 and 8 of Table 3 use data from the global financial crisis of 2008 to estimate the impact of financial flexibility on stock returns. Column 7 uses the period from September 15, 2008, to December 31, 2008. Column 8 uses the period from September 15, 2008, to March 9, 2009, the date on which the CRSP equally weighted index attained its lowest value during the GFC. We construct the sample in the same way that we construct the sample for the COVID-19 shock. All firm characteristics are observed in 2006. The variables used in the regressions are the same as those used in columns 1 and 2 . The coefficient for cash holdings is 0.152 in column 8 and 0.134 in column 1 . The coefficient for long-term debt is -0.131 in column 8 and -0.163 in column 1 . Consequently, the coefficients for cash holdings and long-term debt are quite similar, as is the economic magnitude. A one-standard-deviation lower cash/assets ratio is associated with 3.6\% lower returns (vs. 3.5\% during the COVID-19 crisis) and a one-standard deviation higher long-term debt ratio is associated with $2.5 \%$ lower returns (vs. 3.7\% during the COVID-19 crisis). In contrast, though short-term debt is strongly related to stock returns in 2020, it is not at all related to stock returns following the Lehman bankruptcy, but firms with an investment-grade rating perform much better after that bankruptcy than in March 2020. These results suggest that established firms with low debt were much less affected by the global financial crisis.

\subsection{The rebound in stock prices and financial flexibility}

So far, we have focused on the stock market collapse. The stock market quickly rebounds during April and May 2020 and the period where the financial system is highly stressed is over quickly as well. On September 2, 2020, the S\&P 500 closed at 3580.84 points, a return of $60.0 \%$ from the bottom value of 2237.40 on March 23, 2020. We examine now whether the greater loss experienced by firms with less financial flexibility was attenuated or disappeared during the recovery of the stock market, so that the gap in firm performance between highly flexible firms and low flexibility firms closed somewhat or completely.

The analysis discussed in Section 1 suggests that some of the loss experienced by firms due to a lack of financial flexibility cannot be avoided by firms even with well-functioning financial markets. A financially 
inflexible firm will have to make costly changes to its activities to be able to fund its temporary loss of revenue. However, some of that loss will likely be smaller if financial markets are functioning normally.

Figure 1 provides stark evidence that the greater loss experienced by firms with low financial flexibility does not disappear. It shows the evolution of cumulative daily log excess returns from February 3 to September 11, 2020, for two groups of stocks. The blue-dotted line represents returns for a portfolio of 257 sample firms with high financial flexibility, and the green-dashed line represents returns for a portfolio of 184 sample firms with low financial flexibility. We classify a firm as having high (low) financial flexibility if it is in the top (bottom) quartile of the cash over assets distribution and the bottom (top) quartile of the long-term debt over assets distribution at the end of fiscal year 2019. The figure shows that the cumulative difference in log returns does not shrink after March 23, 2020. By the end of August, the difference between the two groups is more than 20 percentage points.

Figure 1 shows a univariate comparison. It does not account for differential performance of industries. In unreported regressions, we control for the stock, industry, and firm characteristics we examined before. The difference between highly financially flexible firms and all other sample firms by the end of August, controlling for the full set of firm and stock characteristics, is an economically and statistically significant 9.9\%. This evidence shows that lack of financial flexibility is costly to firms when they are faced with a temporary shock to their revenue.

\section{Fundamental Exposure to the COVID-19 Shock, Financial Flexibility, and Stock Returns}

Section 3 examined the relation between financial flexibility and stock returns for all industrial firms. We now more directly focus on the firms most affected by the COVID-19 shock. As we discussed in the introduction, the COVID-19 shock is a supply shock in that production falls for firms that depend on workers being close to each other and a demand shock in that demand falls for firms whose customers have to interact with the firm in person. We start by developing indices of exposure to the COVID-19 shock

based on the exposure of firms to the need for social distancing. We then show how the stock returns of firms most exposed to that need are related to the financial flexibility of these firms. From our analysis of 
Section 1, we expect these firms to benefit especially from financial flexibility and especially from cash holdings as these cash holdings enable them to fund themselves when faced with an abrupt decrease in revenue.

\subsection{Fundamental measures of COVID-19 exposure}

The first measure of exposure we look at is the one developed by Koren and Peto (2020) at the threedigit NAICS industries level. Pagano, Zechner, and Wagner (2020) also use this measure. However, their focus is on stock returns, whereas our focus is on financial flexibility. Koren and Peto (2020) use data on the task description of occupations within industries and data on the geographic location of businesses to classify industries as exposed to COVID-19. Geographic location is relevant in measuring exposure to COVID-19 because risk of exposure to the virus is higher in more dense areas. They use these data to construct three measures: teamwork share, customer share, and presence share. Customer share is a good proxy for the exposure of firms to the demand shock. Teamwork share and presence share are related and proxy for the supply shock as they measure the extent of teamwork and the extent to which workers have occupations that require physical proximity. They aggregate the three measures into one overall measure that they call the affected share. We use the affected share measure as well as its components separately. It is important to note that the distribution of the affected share measure is skewed. There is little variation in the lowest three quartiles of the measure, so we classify a firm as particularly exposed if it belongs to an industry in the top quartile of the affected share measure distribution.

The Koren and Peto (2020) measure ignores the impact of the shock on suppliers of firms that are most exposed to the shock. We create two additional measures of exposure by adding the suppliers to affected firms to the list of exposed firms. The first approach identifies the top-three upstream industries of all NAICS three-digit industries that are particularly affected according to Koren and Peto (2020). For the first classification, we use the vertical relatedness measure of Frésard, Hoberg, and Phillips (2020). The second approach identifies the top-three upstream industries using the Bureau of Economic Analysis USE table instead. 
To these six measures, we add an ex post measure of exposure, which is the Q2 2020 year-on-year change in sales and classify a firm as exposed if its change in sales is in the bottom quartile. Dingel and Neiman (2020) compute the fraction of jobs that can be performed at home across industries. We use the firms in the bottom quartile of their measure, that is, the industries with the fewest jobs that can be performed at home, as our measure of high exposure. Firms that are labor intensive would seem more likely to have high exposure, so that we classify firms that are in the top quartile of employees/sales as highly exposed.

Finally, one problem with the Koren and Peto (2020) measure is that it is not granular enough. A threedigit NAICS industry could have businesses that are brick and mortar businesses or online businesses. These two types of businesses have very different exposures. In addition, the Koren and Peto (2020) measure does not deal well with suppliers to the affected industries, as mentioned above. We therefore examine all industries at the six-digit NAICS level and exclude those industries from the list of affected industries that have more online businesses and include industries that are the main suppliers to affected industries. ${ }^{10}$ Admittedly, this approach is subjective. However, we employ two independent classifications that turn out to quite similarly. Lastly, we use Moody's Investors Service's (Albo et al. 2020) classification of industries most affected by COVID-19.

Appendix C defines all the COVID-19 exposure measures we use and provides summary statistics (Table $\mathrm{C} 1$ ) and a correlation matrix (Table $\mathrm{C} 2$ ). The correlation table shows that the customer share measure is the one most correlated with the Koren and Peto (2020) affected share measure. Perhaps not surprisingly, the affected share measures corrected for upstream relationships are highly correlated with the affected share measure. The ex post measure of change in sales, the share of jobs that can be performed from home, and the labor intensity measure have low correlations with the measures based on the affected share. Finally,

\footnotetext{
${ }^{10}$ For example, while the three-digit NAICS industry 454 is classified as highly affected, we reclassify the subindustry 454110 "Electronic Shopping and Mail-Order Houses" as not affected (e.g., Amazon.com is a member of that subindustry). On the other hand, the three-digit NAICS industry 324 is classified as not affected, and we reclassify subindustry 324110 "Petroleum Refineries" as highly affected (e.g., Exxon Mobil is a member of that subindustry).
} 
the manually classified exposure measure and Moody's industry classification have correlations with the affected share of 0.58 and 0.46 , respectively.

\subsection{Fundamental COVID-19 exposures and stock returns}

To understand the importance of COVID-19 exposure in the stock performance of industries, we show in Table 4 the 20 industries with the worst performance during the COVID-19 collapse period in 2020. For comparison, we show the industries with the worst performance following the bankruptcy of Lehman in 2008. For each industry, we report the affected share measure of Koren and Peto (2020), the ratio of longterm debt to assets, the ratio of PPE to assets, and the cumulative stock return.

The median percentage cumulative return for the 20 industries with the worst performance is $-53.2 \%$ in 2020 and $-63.8 \%$ following the fall of Lehman. We see that nine industries with the worst performance in 2020 also have the worst performance following the bankruptcy of Lehman. However, the industries with the worst performance in 2020 have a much higher COVID-19 exposure than the industries with the worst performance after the bankruptcy of Lehman. The average affected share in 2020 for these industries is 33.9 and the median affected share is 34.5 . In contrast, the average affected share for the worstperforming industries after the bankruptcy of Lehman is 16.4 and the median is 11 , which is less than onethird of the median affected share of the worst-performing industries in 2020. The worst-performing industries after the bankruptcy of Lehman have less leverage and less PPE than the worst-performing industries in 2020. This is especially the case for the ratio of long-term debt to assets as its mean (median) is $0.41(0.37)$ in 2020 and $0.22(0.21)$ after the bankruptcy of Lehman. In summary, as we would expect given the unique nature of the COVID-19 shock, the worst-affected industries by the COVID-19 shock differ in their exposure to the need for social distancing from the worst-affected industries after the Lehman bankruptcy, showing further why a stand-alone analysis of the COVID-19 crisis is valuable.

To assess whether measures of fundamental COVID-19 exposure are important to understand the role of financial flexibility in the reaction of stock prices to the COVID-19 shock, we repeat the regressions of Table 3, but add an indicator variable that takes the value one for firms highly exposed to COVID-19 according to the respective measure and interact that variable with our proxies for financial flexibility. 
Table 5 reports the estimates. We see that highly affected firms perform significantly worse for all our measures except three: the Koren and Peto (2020) presence share measure, the share of jobs that can be performed from home (Dingel and Neiman 2020), and the measure based on labor intensity. For the measures based on affected share, the interactions of the highly affected indicator variable with the financial flexibility proxies show that cash holdings are positively related to stock returns. The coefficient for the cash interaction with these measures is high as it is 0.315 for the measure using the Koren and Peto (2020) affected share and 0.256 for the measure using our manual classification. Using affected share (manual classification), the economic significance of the coefficient for the cash holdings interaction is that a move from the 25th percentile of cash holdings to the 75 th percentile would increase the stock return by 9.0 (7.3) percentage points. Lastly, we see that the coefficients for the noninteracted proxies for financial flexibility are similar to the coefficients in Table 3.

To capture performance during the collapse period, we have so far used stock returns. An alternative measure of returns that avoids some of the pitfalls of market-based measures (e.g., inefficiencies or behavioral biases) is to use accounting returns, such as the return on assets (ROA). Evidence in the literature shows that lack of financial flexibility in the presence of an adverse shock reduces ROA (Giroud et al. 2011). A caveat of using accounting returns is the opaqueness in how financial flexibility affects the impact of the COVID-19 crisis on ROA in the short run. Suppose that a firm loses $x \%$ of revenue as a result of social distancing. It would do so whether or not it has financial flexibility. However, the firm with low financial flexibility will be forced to take costly actions if the decrease in revenue creates financial stress. It may take such actions later in the evolution of the crisis or may have to sell assets or borrow expensively in the short run. The stock market would incorporate the expected cost of these future actions in the stock price even if they do not show up in the first or second quarter ROA. Having said this, it could well be that firms that are highly exposed to COVID-19 would be exposed to financial stress faster because the impact of the crisis on ROA is greater. In this case, more exposed firms would experience higher ROA if they have more financial flexibility. 
We carry out a ROA regression analysis using the operating profits of the first two quarters of 2020 standardized by 2019 total assets. We use the affected share measure of Koren and Peto (2020) as a measure of COVID-19 exposure and interact it with the financial flexibility measures. Table 6 contains the results. Our results show that when we focus on the firms that are more exposed to COVID-19, these firms have worse ROA performance and that highly exposed firms with more cash have higher ROA.

\section{Is It a Leverage Effect?}

It is well-understood that equity is a cushion that absorbs losses of asset value to protect debtholders. A given loss of asset value for a firm affects equity holders more if that firm has more debt. Such an effect would occur even in a world without financial frictions in which financial flexibility has no value per se (Modigliani Miller Proposition II). We call this effect the leverage effect. Documenting that firms with less financial flexibility suffer more from the COVID-19 shock could be just documenting the leverage effect. It is important, therefore, to show that the effect of financial flexibility we estimate is not simply the leverage effect.

The workhorse model in financial economics to assess the impact of asset value changes on the value of equity is Merton (1974). In the first part of this section, we use that model to derive the determinants of the leverage effect. We then show that our evidence is inconsistent with the predictions of the leverage effect and that implementing the Merton (1974) model for the circumstances of the COVID-19 shock suggests that the leverage effect should be largely offset by the impact of the shock on volatilities. In Section 5.2, we provide additional evidence against a mechanical leverage effect as the main explanation for our results.

\subsection{The Merton model and the leverage effect}

Merton (1974) derives the properties of equity as a call option on the value of the assets of the firm. Let $S(t)$ be the value of a firm's equity. This firm has zero-coupon debt that matures at date $T$ with face value $F$. The risk-free interest rate is constant at $r$. The value of the firm's assets at $t$ is $V(t)$. The volatility of the firm's assets is a constant $\sigma$. With this notation, we have that 


$$
S(t)=V(t) \mathrm{N}\left(d_{1}\right)-F e^{-r T} \mathrm{~N}\left(\mathrm{~d}_{2}\right),
$$

where

$$
\mathrm{d}_{1}=\frac{\ln \left(\frac{V}{F}\right)+\left(r+0.5 \sigma^{2}\right) T}{\sigma \sqrt{T}} \text { and } \mathrm{d}_{2}=\mathrm{d}_{1}-\sigma \sqrt{T}
$$

With this formula, it follows that

$$
1 \geq \frac{\partial S}{\partial V} \geq 0, \frac{\partial S}{\partial F}<0, \frac{\partial S}{\partial r}>0, \frac{\partial S}{\partial \sigma^{2}}>0, \frac{\partial S}{\partial T}>0 .
$$

Given the properties of option prices, the value of equity falls when the value of the firm falls and increases when the volatility of the value of the firm increases. The critical issue for our study is whether the percentage decrease in equity for a given percentage decrease in the value of assets is higher for a firm with more leverage. The percentage change in the value of the equity for a given percentage change in the value of the firm is the equity's elasticity with respect to the value of the assets. The value of the equity's elasticity increases with the face value of the debt. Consequently, if two firms are the same except one has more debt, the firm that has more debt has a higher equity elasticity. This is the leverage effect. It has nothing to do with the value of financial flexibility because, by construction, there is no role for financial flexibility in the model as $\mathrm{V}$, the value of the firm, is the same regardless of leverage.

We use a simple calibration of the Merton (1974) model to illustrate the concern. We first calculate the drop in equity value from February 3 to March 23, 2020, for firms with a net leverage ratio (total debt minus cash and cash equivalents) of less than $1 \%$. Since these firms have almost no leverage, the drop in equity value is equivalent to the drop in asset value. We calculate it to be $30.0 \%$ or, as a continuously compounded return $\ln (0.70)=-0.357$. We assume a time-to-maturity of 5 years, an asset volatility of $30 \%$, an interest rate of $3 \%$ and a continuous payout rate of $1 \%$ (the median total payouts/assets) to calculate the equity value for different values of the face value of debt, at the beginning of the sample period, and at the end of the sample period assuming a drop in asset value of $35.6 \%$ in log returns. Panel A of Figure 2 shows the difference in the log of the equity return and the log of the asset return of $35.6 \%$, depending on the leverage 
of the firm. The leverage effect is clearly visible: the higher the leverage, the lower is the equity return relative to the asset return.

One issue with the calibration leading to panel A of Figure 2 is the assumption of a constant asset volatility during the crisis. Equation (5) above shows that a decrease in asset values and an increase in volatility have opposite effects on the value of equity. Consequently, the leverage effect is dampened if volatility increases at the same time as asset values fall. The assumption of a constant asset volatility during the COVID-19 crisis is not tenable, although it is difficult to pin down precisely by how much asset volatility increased. At the start of the collapse period, the VIX is at 17.97. At the end, it is at 61.59. The VIX is a measure of ex ante market volatility. It more than triples over the collapse period. The relevant volatility in Merton (1974) is the firm volatility, which depends on both market volatility and idiosyncratic volatility. In crisis periods, idiosyncratic volatility increases more than market volatility (Bartram, Brown, and Stulz 2019). ${ }^{11}$ However, we would also expect long-term volatility to reflect reversion to the mean, so that appropriate-longer term volatility would increase proportionately less than the VIX. The bottom panel of Figure 2 shows that the volatility effect is very important. The assumptions are exactly the same as before, but now we also vary asset volatility. The figure shows that increases in asset volatility of about 25 percentage points completely offset the mechanical leverage effect, even for leverage levels of under $30 \%$. The bottom panel of Figure 2 shows that the volatility effect is so strong that equity returns can even become less negative than the asset returns during the crisis, and the figure provides evidence against a mechanical leverage effect as explanation for our financial flexibility results.

\subsection{Additional evidence against a mechanical leverage effect}

The mechanical leverage effect is symmetric in Equation (5). A given percentage increase in asset values causes a bigger percentage increase in the equity value for a more levered firm, everything else equal. In Section 3, we therefore already presented one piece of evidence that is inconsistent with the

\footnotetext{
${ }^{11}$ A potential concern could be that the leverage effect means that a decrease in asset value increases stock volatility as well. However, we show that the volatility of asset value increases sharply as well. Further, the equity volatility increase due to the leverage effect may not hold in practice as the literature shows that equity volatility increases with asset value decreases for unlevered firms (Figlewski and Wang 2010; Hasanhodzic and Lo 2011).
} 
leverage effect: firms with low financial flexibility do not perform better when stock prices rebound after March 23, 2020. If the effects we document were simply due to the greater elasticity of the stock price with respect to asset value for more levered firms, we would expect firms with low financial flexibility to perform better when stock prices rebound.

In Section 4, we show that firms more exposed to the COVID-19 shock using fundamental measures of exposure experience a lower percentage fall in the stock price if they have greater cash holdings but do not find that they experience a greater percentage fall in the stock price if they have greater leverage. This finding is also inconsistent with the leverage effect as it would predict a coefficient for leverage at least as large as the coefficient for cash.

\section{The Value of Financial Flexibility, Payouts, and Corporate Diversification}

In Section 3, we found no evidence of a relation between stock returns during the collapse period and corporate payouts in 2019 even when we did not control for our financial flexibility proxies. Since greater corporate payouts, everything else equal, reduce financial flexibility, such a result is puzzling. We investigate this result further and attempt to better understand the relation between payouts and stock return performance in the first part of this section. A diversified corporation can use its internal capital market to substitute in part for external finance. Hence, we would expect corporate diversification to be an advantage for diversified companies that are active both in industries highly affect by the COVID-19 shock and in other industries. We call such companies COVID-19 conglomerates. We investigate whether this is the case in the second part of this section.

\subsection{Payouts and financial flexibility}

The insignificant coefficients for the payout ratio in Table 3 could make sense if the impact of payouts on financial flexibility is small on average. Table 7 presents statistics for our financial flexibility measures and payout ratios for the entire sample and for subsamples based on payout ratio quartiles to assess the extent to which payouts could affect our financial flexibility proxies. We implement a pro forma approach of the type introduced by DeAngelo, DeAngelo, and Stulz (2006), and we estimate what the cash-over- 
assets ratio or the long-term-debt-over-assets ratio would have been at the end of 2019 had the firm had no payouts. We do not take into account the second-order effect that the firm would have to pay less interest since it would have less debt. Columns 1 to 3 show these statistics if we use the 2019 payouts over assets ratio as the main sorting variable. With this approach, we see that the average cash over assets ratio would have only increased from 0.224 to 0.251 had firms not paid out in 2019. The reductions in long-term debt would have been similarly small; the average long-term debt ratio would have only decreased from 0.279 to 0.244 . Using the coefficients of column 1 of Table 3, the stock return would have been higher by 0.36 percentage points $(0.134 \times(0.251-0.224))$ had the firm retained payouts to increase cash or by 0.57 percentage points had the firm retained payouts to reduce long-term debt $(0.163 \times(0.279-0.244))$.

The next five rows report results for the firms that were in the top quartile for the payout ratio in 2019. For them, the average payout over assets ratio increases to 0.111 . But even for those high payout firms, the average cash over assets ratio would have only increased from 0.15 to 0.233 , and the average long-termdebt ratio would have only decreased from 0.316 to 0.204 . The corresponding increases in returns are 1.11 and 1.83 percentage points.

These numbers suggest that total payouts in 2019 were not large relative to the cash balances and debt of companies, not even for top quartile payers. However, sample firms paid out significant amounts not only in 2019 but also in earlier years. Columns 4 to 6 repeat the analysis but now use the cumulative payouts from 2017 to 2019 over assets in 2019 as the sorting variable. ${ }^{12}$

Column 6 shows that the importance of payouts increases. Cumulative payouts are on average $11.4 \%$ of assets. The average cash balance would have increased from 0.199 to 0.272 , while the average long-term debt would have decreased from 0.288 to 0.174 . As a result, the stock return would have been higher by 0.98 or 1.86 percentage points had the payouts been used to increase cash reserves or reduce debt, respectively.

\footnotetext{
12 The number of observations decreases as not all firms have a 3-year history in Compustat.
} 
The mean payout rate for firms in the top quartile of the cumulative payout rate distribution is much higher as it is almost six times larger than the mean payout rate for firms in the middle quartiles (33.7\% versus 5.9\%). If firms in the middle quartiles had not had payouts for the 3 years ending in 2019, the impact on their financial flexibility would be limited. Looking at long-term debt, the long-term debt over assets for the average firm in the middle quartiles would fall from 0.285 to 0.226 . In contrast, for the firms in the top quartile of payout rates, long-term debt over assets would fall from 0.313 to -0.019 , so that on average firms could have paid back their long-term debt and would have had cash left over had they had no payouts for the last 3 years. Using the coefficient for long-term debt of -0.163 from the regression in column 1 of Table 3 to assess the economic impact, firms in the middle quartiles would have had higher returns by 0.96 percentage points had they not had payouts and instead paid down long- term debt while firms in the top quartile would have had higher returns by 5.1 percentage points $(0.163 \times(0.313-0))$.

Given the large difference in payout rates between firms with average cumulative payout rates and firms in the top quartile of cumulative payout rates, we now consider regressions that allow a nonlinear relation between payout rates and stock returns. We define an indicator variable that takes the value one if a firm is in the top quartile of payout rates defined as cumulative 3-year payouts from 2017 to 2019 divided by assets in 2019. We show the estimates in Table 8 and still find that the indicator variable is never significant. Adding the indicator variable has little impact on the coefficients for cash over assets, shortterm debt over assets, and long-term debt over assets.

To understand the surprising result of Table 8 , it is useful to examine which companies have high payout rates when payouts are computed as a percentage of assets. For that purpose, we looked at the 50 firms that have the highest payout rate in 2019. Most firms in that list have assets of less than $\$ 10$ billion. The largest firm in that list is Apple. Apple has \$339 billion in assets; the next largest firm is Cisco with $\$ 98$ billion in assets, and the third largest firm is Biogen that has $\$ 27$ billion in assets. Apple and Cisco have more cash than long-term debt. Biogen Inc. has slightly less cash than long-term debt. But the list also has firms with almost no cash and much long-term debt. An example is Denny's Corp. that paid out 21.2\% of assets, had cash over assets of $1.5 \%$, and had long-term debt equal to $88.5 \%$ of assets. The list suggests 
that the firms with high payout ratios are two different groups of firms: some firms have a very strong balance sheet and are very profitable, and they can have high payouts without weakening their balance sheet. Other firms are extremely highly levered and may have acquired this leverage to finance their payouts. In our regressions, we do not distinguish between types of payers. Further work exploring whether the payout coefficients depend on firm characteristics would be helpful in understanding the relation between payouts and stock returns during the collapse phase better.

A concern with our approach is that we control for industry. Our approach effectively measures whether stock returns differ because of payout rates within industries. It turns out that the results would not be much different if we did not control for industries.

\subsection{Conglomerates and stock returns during the collapse period and on stimulus day}

A considerable literature in finance investigates the costs and benefits of corporate diversification (for a review of the literature, see Maksimovic and Phillips 2013). Though costs are associated with the conglomerate form of organization, one obvious benefit of the conglomerate form of organization is the possibility of funding projects that the financial markets may not fund if under stress. Hence, conglomerates may be in a better position to fund valuable activities during periods of financial stress than specialized firms that undertake the same type of activities. Evidence by Matvos and Seru (2014) and Kuppuswamy and Villalonga (2016) supports the view that conglomerates had some advantages in coping with the stressed financial markets of the GFC. With the COVID-19 crisis, how much the conglomerate form is useful is unclear. Suppose that all activities of a conglomerate face a sudden stop. In this case, the situation of a conglomerate might be similar to the situation of a specialized firm.

In this section, we therefore investigate whether a specific form of conglomerate performed better for a given level of proxies of financial flexibility. A firm is a conglomerate if it has at least two segments operating in different NAICS three-digit industries. A firm is defined as a COVID-19 conglomerate if in addition it has at least one division that is not classified as highly exposed according to the Koren and Peto (2020) measure (i.e., it is not in the top quartile of the affected share distribution) and at least one division that is classified as highly exposed. The maintained hypothesis is that a COVID-19 conglomerate has more 
financial flexibility than a specialized firm for a given level of the financial flexibility proxies because it has an internal capital market.

We use the Compustat Segments database to classify the different divisions of firms. A firm that is in the Compustat Segments database but is active in only one NAICS three-digit industry is designated as a specialized firm. We assume that firms that are not in the Compustat Segments database are specialized firms. With our definition, 107 (5.9\%) sample firms are COVID-19 conglomerates. In Table 9, columns 1 and 2, we reestimate the regressions of Table 3, columns 1 and 2, and include an indicator variable that takes the value of one if a firm is a diversified COVID-19 conglomerate as well as an indicator variable that takes the value of one if a firm is in an affected industry but is not a COVID-19 conglomerate. We drop the industry fixed effects to make sure that these fixed effects do not prevent us from assessing correctly the effect of corporate diversification since conglomerate firms operate in multiple industries. If corporate diversification benefits firms that are active in highly exposed industries, we would expect them to have better performance than single-segment firms in the same industries with the same financial flexibility. We find that conglomerate firms in highly exposed industries do not perform worse than firms that are not in highly exposed industries. In contrast, single-segment firms in highly exposed industries perform worse as we already know. However, the evidence is mixed in that conglomerate firms do not perform significantly better than firms in highly exposed industries that are not conglomerates at (the p-value for a one-sided test in column 1 is 0.125 ) even though the difference in performance is economically significant. The regression in column 3 suggests that the problem is, at least in part, a power problem because we have so few COVID19 conglomerates. In that regression, we interact the indicator variables with the financial flexibility proxies. We see that the coefficient for cash is not significant for COVID-19 conglomerates and is substantially smaller than for specialized firms in highly exposed industries. However, the coefficient for leverage is similar for COVID-19 conglomerates and specialized firms in highly exposed industries, but it is only significant for specialized firms.

Table 9 provides some evidence that points to the conglomerate form being valuable during the collapse period in the COVID-19 crisis and that the benefits from corporate diversification substitute for the benefits 
of financial flexibility. Conglomerate firms do not perform worse than firms that are not in highly exposed industries, and cash does not seem as valuable for these firms as it is for specialized firms in highly exposed industries. At the same time, we cannot reject the hypothesis that COVID-19 conglomerates perform the same than specialized firms in affected industries. Our inferences would likely be stronger if there were more COVID-19 conglomerates.

\section{Financial Constraints and the Cross-Section of Stock Returns}

In this section, we address the issue of whether the firms we identify as financially inflexible are firms that the literature would have identified as financially constrained. We investigate whether the various indexes and measures of financial constraints help explain the cross-section of excess returns during the collapse period as well as during stimulus day.

In Table 10, we estimate regressions of stock returns on firm characteristics known to be related to asset returns from the asset pricing literature and include industry fixed effects, but instead of having variables that proxy for financial flexibility, we include indicator variables that measure whether firms are financially constrained (KZ, WW, and SA indexes and the HM measure), or that measure whether firms have a projected cash deficit (HR cash ex ante measure). In other words, the table answers the question of whether the most financially constrained firms perform worse during the collapse period and better on stimulus day than other firms. For the traditional three financial constraints indexes, columns $1-6$ of Table 10 show that there is no evidence that the most constrained firms exhibit worse returns when we control for firm characteristics and industry fixed effects. Surprisingly, the firms that are highly constrained according to the Whited-Wu index actually performed better during the collapse period.

We conjectured when developing Hypothesis 2 that we may not find evidence for a negative effect of financial constraints on stock prices during the collapse period because these firms could have large precautionary cash holdings. Specifically, a firm might be unable to access capital markets, but if its precautionary cash holdings are large enough, it can fund itself for the period of the sudden revenue stop. 
The HM measure of financial constraints focuses on firms with disclosed liquidity needs and a resultant potential for underinvestment and thus addresses the concern above. Indeed, we find that firms that are considered financially constrained according to the HM measure have worse stock returns during the collapse period, and fare better on stimulus day. The coefficients in columns 7 and 8 show that companies that are financially constrained according to Hoberg and Maksimovic (2015) have 4.5 percentage points lower returns during the collapse period, and 1.2 percentage points higher returns on stimulus day.

In contrast to the traditional measures of financial constraints, such as the KZ and WW indexes, the Huang-Ritter measure explicitly focuses on the ability of firms to fund themselves out of their existing cash holdings. We find in column 9 of Table 10 that it is significant and has the expected sign; namely, firms that would run out of cash absent outside finance are firms that perform worse during the collapse period. The effect is economically large. Firms with a projected cash deficit have returns lower by 3.5 percentage points during the collapse period.

Overall, we find that the older measures of financial constraints are not helpful in understanding the cross-sectional variation in stock returns during the collapse period. In contrast, the new measures that do not rely on coefficients of regressions but that are focused on what firms say (the HM measure) or on what funding firms require (the Huang-Ritter measure) show that firms that are not financially constrained perform better during the collapse period.

\section{Conclusion}

We examine the value of financial flexibility in the unique situation of a sudden and unexpected revenue shortfall brought about by demand and supply shocks related to the increase in the need for social distancing associated with the COVID-19 shock. Across all firms, we find that, everything else equal, the revenue shortfall affects a firm's stock less if the firm is more financially flexible. This benefit of financial flexibility is economically important. The difference between the stock price drop of a firm with high financial flexibility and the stock price drop of a firm with low financial flexibility is equal to $26 \%$ of the stock price drop of the average firm. We also investigate how firms' stock prices react to news of macroeconomic 
measures designed to attenuate the shock. We expect that firms with more financial flexibility benefit less from these measures. We find that this is the case, but only for long-term debt over assets and not for cash holdings. Though one would expect that payouts reduce financial flexibility, there is no evidence that firms with higher payouts are affected more adversely by the COVID-19 shock in our regressions.

We construct several different measures of firm exposure to greater need for social distancing. We then use these measures to examine whether firms more exposed to the COVID-19 shock benefit more from financial flexibility. We generally find that highly affected firms have significantly lower stock returns, but that the stock price drop is economically and statistically significantly smaller if they have more cash. The additional benefit of cash holdings is large. A firm in the 75th percentile of cash holdings has a stock price drop lower by $7.3-9$ percentage points than a firm in the 25 th percentile.

An important concern is whether our results arise mechanically due to a leverage effect, which implies that equity is riskier for firms with higher leverage. We show that this is not the case for three reasons. First, during March, volatility increases sharply which lowers or even eliminates the leverage effect. Second, the leverage effect predicts that low financial flexibility firms should perform better when stocks rebound, which is not the case. Third, for the firms highly exposed to the greater need for social distancing, we find that they benefit more from greater cash holdings than other firms, but not from lower debt, while the leverage effect would predict similar effects for cash holdings and debt.

Though financial economists have argued that financial flexibility might be used to hurt shareholders (Jensen 1986), investor activists have campaigned to force firms to decrease cash holdings and increase leverage, and the private equity industry has made the reduction of financial flexibility intrinsic to its business model, the results of this paper should remind us that financial flexibility is also a key risk management tool. However, this tool does not come for free. Future research should help us understand better how to value the downside of financial flexibility to help shareholders and managers trade off the benefits and costs of financial flexibility more effectively. 


\section{References}

Acharya, V., and S. Steffen. 2020. The risk of being a fallen angel and the corporate dash for cash in the midst of COVID. Review of Corporate Finance Studies 9:430-71.

Albo, M, B. Chung, R. Morawetz, and S. Veseli. 2020. Companies - EMEA: Coronavirus will curb profitability and test the liquidity of lower rated companies. Report, Moody's Investors Service, New York City, NY.

Albuquerque, R., Y. Koskinen, S. Yang, and C. Zhang. 2020. Resiliency of environmental and social stocks: An analysis of the exogenous COVID-19 market crash. Review of Corporate Finance Studies 9:593-621.

Almeida, H., M. Campello, B. Laranjeira, and S. Weisbenner. 2011. Corporate debt maturity and the real effects of the 2007 credit crisis. Critical Finance Review 1:3-58.

Almeida, H., M. Campello, and M. Weisbach. 2004. The cash flow sensitivity of cash. Journal of Finance 59:1777-804.

Baqaee, D., and E. Farhi. 2020. Supply and demand in disaggregated Keynesian economics with an application to the COVID-19 crisis. Working Paper, University of California, Los Angeles.

Bartram, S., G. Brown, and R. Stulz. 2019. Why is there a secular decline in idiosyncratic risk in the 2000s? Working Paper, Warwick Business School, University of Warwick.

Bernanke, B., and M. Gertler. 1989. Agency costs, net worth, and business fluctuations. American Economic Review 79:14-31.

Campello, M., J. Graham, and C. Harvey. 2010. The real effects of financial constraints: Evidence from a financial crisis. Journal of Financial Economics 97:470-87.

Carhart, M. 1997. On persistence in mutual fund performance. Journal of Finance 52:57-82.

Chodorow-Reich, G. 2014. The employment effects of credit market disruptions: Firm-level evidence from the 2008-09 financial crisis. Quarterly Journal of Economics 129:1-59.

DeAngelo, H., and L. DeAngelo. 2009. Capital structure, payout policy, and financial flexibility. Working Paper, Marshall School of Business, University of Southern California.

DeAngelo, H., L. DeAngelo, and R. Stulz. 2006. Dividend policy and the earned/contributed capital mix: a test of the life-cycle theory. Journal of Financial Economics 81:227-54.

DeAngelo, H., A. Gonçalves, and R. Stulz. 2018. Corporate deleveraging and financial flexibility. Review of Financial Studies 31:3122-74.

Denis, D. 2011. Financial flexibility and corporate liquidity. Journal of Corporate Finance 17:667-74.

De Vito, A., and J. Gómez. 2020. Estimating the COVID-19 cash crunch: Global evidence and policy. Journal of Accounting and Public Policy 39:1-14.

Ding, W., R. Levine, C. Lin, and W. Xie. Forthcoming. Corporate immunity to the COVID-19 pandemic. Journal of Financial Economics.

Dingel, J. I., and B. Neiman. 2020. How many jobs can be done at home? Journal of Public Economics 189:104235.

Duchin, R., O. Ozbas, and B. Sensoy. 2010. Costly external finance, corporate investment, and the subprime mortgage credit crisis. Journal of Financial Economics 97:418-35.

Eldar, O., and M. Wittry. Forthcoming. The return of poison pills: An analysis of "crisis pills" adopted in the COVID-19 pandemic. Review of Corporate Finance Studies. 
Fahlenbrach, R., R. Prilmeier, and R. Stulz. 2012. This time is the same: Using bank performance in 1998 to explain bank performance during the recent financial crisis. Journal of Finance 67:2139-85.

Fama, E., and K. French. 1993. Common risk factors in the returns on stocks and bonds. Journal of Financial Economics 33:3-56.

2015. A five-factor asset pricing model. Journal of Financial Economics 116:1-22.

Fama, E., and M. Miller. 1972. The theory of finance. Hinsdale, IL: Dryden Press.

Fazzari, S., R. Hubbard, and B. Petersen. 1988. Financing constraints and corporate investment. Brookings Papers on Economic Activity 1:141-206.

Figlewski, S., and X. Wang. 2000. Is the 'leverage effect' a leverage effect? Working Paper, Leonard N. Stern School of Business, New York University.

Frésard, L., G. Hoberg, and G. Phillips. 2020. Innovation activities and integration through vertical acquisitions. Review of Financial Studies 33:2937-76.

Galai, D., and R. Masulis. 1976. The option pricing model and the risk factor of stock. Journal of Financial Economics 3:53-81.

Giroud, X., and H. Mueller. 2017. Firm leverage, consumer demand, and employment losses during the Great Recession. Quarterly Journal of Economics 132:271-316.

Giroud, X., H. Mueller, A. Stomper, and A. Westerkamp. 2011. Snow and leverage. Review of Financial Studies 25:680-710.

Graham, J., and C. Harvey. 2001. The theory and practice of corporate finance: Evidence from the field. Journal of Financial Economics 60:187-243.

Hadlock, C., and J. Pierce. 2010. New evidence on measuring financial constraints: Moving beyond the KZ index. Review of Financial Studies 23:1909-40.

Hamada, R. 1972. The effects of the firm's capital structure on the systematic risk of common stocks. Journal of Finance 27:435-52.

Hasanhodzic, J., and A. Lo. 2011. Black's leverage effect is not due to leverage. Working Paper, Babson College.

Hassan, T., S. Hollander, L. van Lent, and A. Tahoun. 2020. Firm-level exposure to epidemic diseases: Covid-19, SARS, and H1N1. Working Paper, Boston University.

Hoberg, G., and V. Maksimovic. 2015. Redefining financial constraints: A text-based analysis. Review of Financial Studies 28:1312-52.

Huang, R., and J. Ritter. 2020. Corporate cash shortfalls and financing decisions. Review of Financial Studies. Advance Access published August 26, 2020, 10.1093/rfs/hhaa099.

Ivashina, V., and D. Scharfstein. 2010. Bank lending during the financial crisis of 2008. Journal of Financial Economics 97:319-38.

Jensen, M. 1986. Agency costs of free cash flow, corporate finance, and takeovers. American Economic Review 76:323-29.

Kahle, K., and R. Stulz. 2013. Access to capital, investment, and the financial crisis. Journal of Financial Economics 110:280-99.

Kahle, K., and R. Stulz. 2020. Are corporate payouts abnormally high in the 2000s? Working Paper, Eller College of Management, University of Arizona. 
Kaplan, S., and L. Zingales. 1997. Do investment-cash flow sensitivities provide useful measures of financing constraints? Quarterly Journal of Economics 112:169-215.

Koren, M., and R. Peto. 2020. Business disruptions from social distancing. Covid Economics 2:13-31.

Kuppuswamy, V., and B. Villalonga. 2016. Does diversification create value in the presence of external financing constraints? Evidence from the 2007-2009 financial crisis. Management Science 62:905-23.

Lamont, O., C. Polk, and J. Saá-Requejo. 2001. Financial constraints and stock returns. Review of Financial Studies 14:529-54.

Li, L., P. Strahan, and S. Zhang. 2020. Banks as lenders of first resort: Evidence from the COVID-19 crisis. Review of Corporate Finance Studies 9:472-500.

Loughran, T., and B. McDonald. 2020. Management disclosure of risk factors and COVID-19. Working Paper, University of Notre Dame.

Maksimovic, V., and G. Phillips. 2013. Conglomerate firms, internal capital markets, and the theory of the firm. Annual Review of Financial Economics 5:225-44.

Matvos, G., and A. Seru. 2014. Resource allocation within firms and financial market dislocation: Evidence from diversified conglomerates. Review of Financial Studies 27:1143-89.

Merton, R. 1974. On the pricing of corporate debt: the risk structure of interest rates. Journal of Finance 29:449-70.

Modigliani, F., and M. Miller. 1958. The cost of capital, corporation finance, and the theory of investment. American Economic Review 48:261-97.

Novy-Marx, R. 2013. The other side of value: The gross profitability premium. Journal of Financial Economics 108:1-28.

Opler, T., L. Pinkowitz, R. Stulz, and R. Williamson. 1999. The determinants and implications of corporate cash holdings. Journal of Financial Economics 52:3-46.

Pagano, M., C. Wagner, and J. Zechner. 2020. Disaster resilience and asset prices. Working Paper, University of Naples Federico II.

Papanikolaou, D., and L. Schmidt. 2020. Working remotely and the supply-side impact of Covid-19. Working Paper, Kellogg School of Management, Northwestern University.

Plender, J. 2020. Wave of corporate defaults owes much to foolhardy share buybacks. Financial Times, April 29.

Ramelli, S., and A. Wagner. 2020. Feverish stock price reactions to COVID-19. Review of Corporate Finance Studies 9:622-55.

Schlesinger, J. 2020. Coronavirus stimulus package to include curbs on share buybacks. Wall Street Journal, March 25.

Shleifer, A., and R. Vishny. 1992. Liquidation values and debt capacity: A market equilibrium approach. Journal of Finance 47:1343-66.

- 2011. Fire sales in finance and macroeconomics. Journal of Economic Perspectives 25:29-48.

Stulz, R. 1990. Managerial discretion and optimal financing policies. Journal of Financial Economics 26:327.

Whited, T., and G. Wu. 2006. Financial constraints risk. Review of Financial Studies 19:531-59. 
Appendix A

Sample selection procedure

Compustat North America Daily - Fundamentals Annual

Number of firms with fiscal year 2019 data available in April 2020

3,859

Drop firms with

Duplicate data

SIC codes 6000-6999 (financial firms)

$-1,230$

SIC codes 4900-4949 (utility firms)

$-97$

SIC codes 8000s and 9000s (not-for-profit and governmental firms)

$-116$

Non-U.S. headquarters

$-410$

Missing cash and short-term investments

$-2$

Missing stock price data in Compustat North America Daily - Security Daily

An average share price $<\$ 1$

$-88$

Security type not equal to "common, ordinary"

$-2$

Number of firms after all screens 


\section{Appendix B}

Variable definitions

This appendix contains the definitions of all dependent and independent variables. Compustat data item mnemonics are in capitalized letters.

\begin{tabular}{|c|c|}
\hline Variable name & Description \\
\hline \multicolumn{2}{|c|}{ Dependent variables } \\
\hline Daily exc. return & $\begin{array}{l}\text { The natural logarithm of }\left(1+r-r_{f}\right) \text {, where } r \text { equals the daily simple return based on } \\
\text { the daily close price (PRCCD in Compustat Security Daily) adjusted for the daily } \\
\text { total return factor (TRFD) and the daily adjustment factor (AJEXDI) and } r_{f} \text { is the 1- } \\
\text { month daily Treasury-bill rate }\end{array}$ \\
\hline ROA & The ratio of operating income before depreciation to total assets; OIBDP / AT \\
\hline
\end{tabular}

\section{Independent and other variables}

Assets (\$m)

Cash / assets

St debt / assets

nSt debt / assets

Lt debt / assets

Book debt / assets

Payout / assets

Ind: 3-year cum. payout / assets top quartile

Ind: COVID-19

conglomerate

Ind: IG debt rating

Ind: HY debt rating

$\mathrm{RD} /$ assets

SGA / sales

Capex / lagged assets

COGS / sales

Equity beta
The book value of total assets; AT

The ratio of cash to total assets; CHE / AT

The ratio of debt in current liabilities to total assets; DLC / AT.

Short-term debt scaled by total assets minus cash scaled by total assets

The ratio of total long-term debt to total assets; DLTT / AT

The ratio of total book debt to total assets; (DLC + DLTT) / AT

The ratio of total dividends and share repurchases to total assets; (DVC + DVP + PRSTKC) / AT. We set missing or negative DVC, DVP, and PRSTKC to zero

An indicator variable set to one if the sum of the firm's total payouts in year 2017, 2018, and 2019 scaled by the firm's total assets in 2019 is in the top quartile of the distribution and set to zero otherwise

An indicator variable set to one if the firm generates sales from two or more business segments belonging to different NAICS three-digit industries and if the sum of sales of these segments lies within an interval of one percentage point from the firm's aggregate sales. Furthermore, the firm has at least one division that is not classified as highly exposed according to the Koren and Peto (2020) measure (i.e., not be in the top quartile of the affected share distribution) and at least one division that is classified as highly exposed. Otherwise, the indicator is set to zero. Segments data are retrieved from the Compustat Segments (nonhistorical) database

An indicator variable set to one if the firm's S\&P domestic long-term issuer credit rating (SPLTICRM in the Compustat ratings file) at the end of February 2017 is at or above $\mathrm{BBB}-$ and set to zero otherwise

An indicator variable set to one if the firm's S\&P domestic long-term issuer credit rating (SPLTICRM in the Compustat ratings file) at the end of February 2017 is between $\mathrm{BB}+$ and $\mathrm{C}$ and set to zero otherwise

The ratio of research and development expense to total assets; XRD / AT. We set missing XRD to zero

The ratio of selling, general, and administrative expense to total sales; XSGA / SALE The ratio of capital expenditures to total assets lagged by one year; CAPX / AT The ratio of cost of goods sold to total sales capped at 100\%; COGS / SALE The slope parameter of a regression of daily log excess returns on daily market log excess returns from January 2 to December 31, 2019 
BM at EoY 2019

$\ln (\mathrm{MVE})$ at EoY 2019

Momentum 2019

Profitability
The ratio of book value of equity (CEQ) to market value of equity at year-end 2019, which equals the last observation of daily close price (PRCCD) at year-end 2019 multiplied with the number of shares outstanding (CSHOC)

The natural logarithm of the firm's last observation of daily close price (PRCCD) at year-end 2019 multiplied with its number of shares outstanding (CSHOC)

The exponent of the sum of daily log excess returns from January 2, 2019, to the last observation of daily log excess returns at year-end 2019

The ratio of gross profit to total assets; GP / AT

Financial constraints indexes / measures:

$\mathrm{KZ}$ index

FC (KZ index)

WW index

FC (WW index)

SA index

FC (SA index)

HM measure

FC(HM measure $)$

HR cash ex ante

FC (HR cash ex ante)
The Kaplan and Zingales (KZ) index, which we construct following Lamont, Polk, and Saá-Requejo (2001)

An indicator variable set to one if the firm's $\mathrm{KZ}$ index is in the top quartile of the distribution and set to zero otherwise

The Whited and $\mathrm{Wu}$ (WW) index, which we construct following Whited and $\mathrm{Wu}$ (2006)

An indicator variable set to one if the firm's WW index is in the top quartile of the distribution and set to zero otherwise

The Size-Age index of Hadlock and Pierce (2010)

An indicator variable set to one if the firm's SA index is in the top quartile of the distribution and set to zero otherwise

The "Delay Investment Score" overall financial constraint measure of Hoberg and Maksimovic (2015)

An indicator variable set to one if the firm's HM measure is in the top quartile of the distribution and set to zero otherwise

The cash ex ante variable, which we construct as in Huang and Ritter (2019);

$2 \times$ CHE2019 - CHE2018 - (DLTIS2019 - DLTR2019 + DLCCH2019) (SSTK2019 - PRSTKC2019). We set missing SSTK, PRSTKC, DLTIS, and DLTR to zero. We set missing DLCCH2019 to DLC2019 - DLC2018

An indicator variable set to one if the firm's HR cash ex ante variable is in the top quartile of the distribution and set to zero otherwise 


\section{Appendix C \\ Different measures of COVID-19 exposure of firms/industries}

1. Affected share as defined by Koren and Peto (2020) at the three-digit NAICS level. Exposed firms belong to industries in the top quartile of the affected share distribution.

2. Teamwork share as defined by Koren and Peto (2020) at the three-digit NAICS level. Measures the percentage of workers in teamwork-intensive occupations. Exposed firms belong to industries in the top quartile of the teamwork share distribution.

3. Customer share as defined by Koren and Peto (2020) at the three-digit NAICS level. Measures the percentage of workers in customer-facing occupations. Exposed firms belong to industries in the top quartile of the customer share distribution.

4. Presence share as defined by Koren and Peto (2020) at the three-digit NAICS level. Measures the percentage of workers in occupations requiring physical contact. Exposed firms belong to industries in the top quartile of the presence share distribution.

5. The affected share measure of Koren and Peto (2020) plus the three most important upstream industries across all affected three-digit NAICS industries, as measured by vertical relatedness based on Frésard, Hoberg, and Phillips (2020). Exposed firms belong to industries in the top quartile of the affected share distribution or to the three most important upstream industries of affected industries.

6. The affected share measure of Koren and Peto (2020) plus the three most important upstream industries across all affected three-digit NAICS industries as measured by the Bureau of Economic Analysis USE table. Exposed firms belong to industries in the top quartile of the affected share distribution or to the three most important upstream industries of affected industries

7. Q2 2020 year-on-year change in sales, defined at the firm level. Exposed firms are the ones in the bottom quartile of the change in sales.

8. Share of jobs that can be performed at home from Dingel and Neiman (2020), defined at the threedigit NAICS industry level. Exposed firms are part of industries in the bottom quartile of the distribution.

9. Labor intensity as number of employees / sales (to proxy for total payroll / sales), defined at the firm level. Exposed firms are the ones in the top quartile of the labor intensity distribution.

10. Manual classification of industries at the six-digit NAICS level. Exposed firms are part of the industries manually classified as exposed.

11. Indicator variable equal to one for all firms that are part of the Fama-French 49 industries identified by Moody's Investors Service (Albo et al. 2020) as particularly exposed to COVID-19, and equal to zero otherwise. 
Table C1

\section{Summary statistics}

The table presents summary statistics for the raw data as well as our derived different measures of COVID-19 exposure of firms/industries. Appendix C defines all variables.

\begin{tabular}{|c|c|c|c|c|c|c|}
\hline & $\mathrm{N}$ & $\mathrm{P} 25$ & Median & Mean & $\mathrm{P} 75$ & SD \\
\hline Affected share & 1,841 & 9.000 & 10.000 & 15.878 & 16.000 & 15.738 \\
\hline Teamwork share & 1,841 & 17.000 & 25.000 & 24.968 & 25.000 & 10.981 \\
\hline Customer share & 1,841 & 7.000 & 8.000 & 15.448 & 18.000 & 16.316 \\
\hline Customer share (TQ) & 1,841 & 0.000 & 0.000 & 0.243 & 0.000 & 0.429 \\
\hline Presence share & 1,841 & 3.000 & 9.000 & 10.367 & 11.000 & 12.498 \\
\hline Presence share (TQ) & 1,841 & 0.000 & 0.000 & 0.198 & 0.000 & 0.398 \\
\hline Q2 2020 year-on-year change in sales & 1,581 & -0.305 & -0.094 & -0.071 & 0.079 & 0.487 \\
\hline Q2 2020 year-on-year change in sales (BQ) & 1,581 & 0.000 & 0.000 & 0.250 & 1.000 & 0.433 \\
\hline Share of jobs that can be performed from home & 1,854 & 0.209 & 0.278 & 0.383 & 0.506 & 0.240 \\
\hline Share of jobs that can be performed from home (BQ) & 1,854 & 0.000 & 0.000 & 0.251 & 1.000 & 0.434 \\
\hline Labor intensity as number of employees / sales & 1,562 & 0.002 & 0.003 & 0.005 & 0.005 & 0.011 \\
\hline Labor intensity as number of employees / sales (TQ) & 1,562 & 0.000 & 0.000 & 0.250 & 0.000 & 0.433 \\
\hline
\end{tabular}

\section{Table C2}

\section{Correlation matrix}

The table presents the correlation matrix for the different measures of COVID-19 exposure of firms/industries. Appendix C defines all variables.

\begin{tabular}{|c|c|c|c|c|c|c|c|c|c|c|c|}
\hline & $(1)$ & $(2)$ & (3) & (4) & $(5)$ & $(6)$ & $(7)$ & $(8)$ & $(9)$ & $(10)$ & $(11)$ \\
\hline (1) Affected share (TQ) & 1 & & & & & & & & & & \\
\hline (2) Teamwork share (TQ) & 0.14 & 1 & & & & & & & & & \\
\hline (3) Customer share (TQ) & 0.59 & 0.3 & 1 & & & & & & & & \\
\hline (4) Presence share (TQ) & 0.18 & $0.11-$ & -0.18 & 1 & & & & & & & \\
\hline (5) Affected share corrected for Frésard, Hoberg, and Phillips 2020 (TQ) & 0.96 & 0.12 & 0.57 & 0.24 & 1 & & & & & & \\
\hline (6) Affected share corrected for BEA & 0.93 & 0.23 & 0.67 & 0.15 & 0.9 & 1 & & & & & \\
\hline (7) Q2 2020 year-on-year change in sales (BQ) & 0.28 & 0 & 0.05 & 0.09 & 0.27 & 0.24 & 1 & & & & \\
\hline (8) Share of job & $0.25-$ & -0.26 & 0.15 & 0.17 & 0.3 & 0.21 & 0.13 & 1 & & & \\
\hline (9) Labor intensity as number of em & 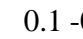 & -0.04 & 0.19 & -0.18 & 0.08 & 0.12 & 0.03 & 0.05 & 1 & & \\
\hline (10) Manual classifica & 0.58 & 0.02 & 0.28 & 0.26 & 0.56 & 0.54 & 0.43 & 0.45 & 0.07 & . & \\
\hline (11) Ind: COVID-19 industries classified by Moody's Investors Service & $0.46-($ & -0.08 & 0.38 & 0.14 & 0.45 & 0.45 & 0.15 & 0.36 & 0.1 & 0.47 & 1 \\
\hline
\end{tabular}


Table 1

\section{Summary statistics}

The table presents summary statistics for the dependent and independent variables we use. The sample consists of all nonfinancial and nonutility firms with available fiscal year 2019 data in Compustat. Appendix A shows the sample selection procedure. Appendix B defines all variables. GFC, global financial crisis.

\begin{tabular}{|c|c|c|c|c|c|c|c|c|c|c|c|c|}
\hline & $\mathrm{N}$ & Min & $\mathrm{P} 1$ & P5 & $\mathrm{P} 25$ & Median & Mean & $\mathrm{P} 75$ & $\mathrm{P} 95$ & P99 & Max & $\mathrm{SD}$ \\
\hline \multicolumn{13}{|l|}{ Dependent variables: } \\
\hline $\begin{array}{l}\text { COVID-19-related } \\
\text { Cum. daily exc. returns (Feb 2, 2020, to March 23, } \\
\text { 2020) }\end{array}$ & 1,858 & -0.905 & -0.826 & -0.712 & -0.523 & -0.387 & -0.378 & -0.261 & -0.055 & 0.248 & 3.503 & 0.260 \\
\hline Daily exc. returns (March 24, 2020) & 1,857 & -0.655 & -0.107 & -0.019 & 0.046 & 0.087 & 0.092 & 0.132 & 0.229 & 0.326 & 0.520 & 0.079 \\
\hline ROA (cumulative Q1 + Q2 2020) & 1,762 & -0.646 & -0.646 & -0.296 & -0.023 & 0.034 & -0.006 & 0.062 & 0.122 & 0.219 & 0.219 & 0.137 \\
\hline \multicolumn{13}{|l|}{ GFC-related } \\
\hline $\begin{array}{l}\text { Cum. daily exc. returns (Sep 15, 2008, to Dec 31, 2008) } \\
\text { Cum. daily exc. returns (Sep 15, 2008, to March 9, } \\
\text { 2009) }\end{array}$ & $\begin{array}{l}2,435 \\
2,426\end{array}$ & $\begin{array}{l}-0.962 \\
-0.996\end{array}$ & $\begin{array}{l}-0.875 \\
-0.951\end{array}$ & $\begin{array}{l}-0.751 \\
-0.876\end{array}$ & $\begin{array}{l}-0.535 \\
-0.694\end{array}$ & $\begin{array}{l}-0.374 \\
-0.538\end{array}$ & $\begin{array}{l}-0.370 \\
-0.508\end{array}$ & $\begin{array}{l}-0.219 \\
-0.375\end{array}$ & $\begin{array}{r}0.014 \\
-0.098\end{array}$ & $\begin{array}{l}0.275 \\
0.208\end{array}$ & $\begin{array}{r}1.088 \\
22.316\end{array}$ & $\begin{array}{l}0.242 \\
0.531\end{array}$ \\
\hline \multicolumn{13}{|l|}{ Independent and other variables: } \\
\hline Assets (\$m) & 1,857 & 7.783 & 10.113 & 37.700 & 362.359 & 1415.693 & 7350.789 & 4843.531 & $3.7 \mathrm{e}+04$ & $1.4 \mathrm{e}+05$ & $1.4 \mathrm{e}+05$ & $1.9 \mathrm{e}+04$ \\
\hline Cash / assets & 1,857 & 0.001 & 0.001 & 0.005 & 0.038 & 0.112 & 0.224 & 0.324 & 0.844 & 0.961 & 0.961 & 0.261 \\
\hline St debt / assets & 1,847 & 0.000 & 0.000 & 0.000 & 0.005 & 0.013 & 0.032 & 0.036 & 0.122 & 0.331 & 0.381 & 0.054 \\
\hline nSt debt / assets & 1,847 & -0.959 & -0.959 & -0.832 & -0.289 & -0.082 & -0.192 & -0.009 & 0.055 & 0.251 & 0.299 & 0.273 \\
\hline Lt debt / assets & 1,841 & 0.000 & 0.000 & 0.000 & 0.089 & 0.259 & 0.279 & 0.409 & 0.684 & 1.068 & 1.106 & 0.226 \\
\hline Book debt / assets & 1,835 & 0.000 & 0.000 & 0.001 & 0.115 & 0.296 & 0.312 & 0.451 & 0.730 & 1.132 & 1.174 & 0.238 \\
\hline Payout / assets & 1,857 & 0.000 & 0.000 & 0.000 & 0.000 & 0.011 & 0.035 & 0.042 & 0.160 & 0.347 & 0.347 & 0.059 \\
\hline Ind: 3-year cum. payout / assets top quartile & 1,679 & 0.000 & 0.000 & 0.000 & 0.000 & 0.000 & 0.250 & 1.000 & 1.000 & 1.000 & 1.000 & 0.433 \\
\hline Ind: COVID-19 conglomerate & 1,857 & 0.000 & 0.000 & 0.000 & 0.000 & 0.000 & 0.058 & 0.000 & 1.000 & 1.000 & 1.000 & 0.233 \\
\hline Ind: IG debt rating & 1,857 & 0.000 & 0.000 & 0.000 & 0.000 & 0.000 & 0.146 & 0.000 & 1.000 & 1.000 & 1.000 & 0.353 \\
\hline Ind: $\mathrm{HY}$ debt rating & 1,857 & 0.000 & 0.000 & 0.000 & 0.000 & 0.000 & 0.190 & 0.000 & 1.000 & 1.000 & 1.000 & 0.392 \\
\hline $\mathrm{RD} /$ assets & 1,857 & 0.000 & 0.000 & 0.000 & 0.000 & 0.012 & 0.079 & 0.089 & 0.391 & 0.819 & 0.886 & 0.151 \\
\hline SGA / sales & 1,626 & 0.019 & 0.019 & 0.043 & 0.117 & 0.229 & 0.386 & 0.430 & 1.073 & 3.679 & 5.251 & 0.604 \\
\hline Capex / lagged assets & 1,690 & 0.000 & 0.000 & 0.003 & 0.015 & 0.030 & 0.045 & 0.058 & 0.149 & 0.242 & 0.242 & 0.047 \\
\hline COGS / sales & 1,857 & 0.000 & 0.056 & 0.162 & 0.416 & 0.629 & 0.607 & 0.800 & 1.000 & 1.000 & 1.000 & 0.254 \\
\hline $\mathrm{KZ}$ index & 1,572 & -481.155 & -229.066 & -50.300 & -3.734 & 0.689 & -6.342 & 2.791 & 12.266 & 76.518 & 319.574 & 42.702 \\
\hline $\mathrm{FC}(\mathrm{KZ}$ index $)$ & 1,572 & 0.000 & 0.000 & 0.000 & 0.000 & 0.000 & 0.249 & 0.000 & 1.000 & 1.000 & 1.000 & 0.433 \\
\hline WW index & 1,657 & -0.598 & -0.572 & -0.518 & -0.418 & -0.345 & -0.327 & -0.266 & -0.050 & 0.079 & 0.253 & 0.136 \\
\hline FC (WW index) & 1,657 & 0.000 & 0.000 & 0.000 & 0.000 & 0.000 & 0.249 & 0.000 & 1.000 & 1.000 & 1.000 & 0.433 \\
\hline SA index & 1,857 & -4.637 & -4.633 & -4.576 & -4.014 & -3.405 & -3.435 & -3.009 & -2.137 & -1.247 & -0.410 & 0.741 \\
\hline FC (SA index $)$ & 1,857 & 0.000 & 0.000 & 0.000 & 0.000 & 0.000 & 0.249 & 0.000 & 1.000 & 1.000 & 1.000 & 0.433 \\
\hline HR cash ex ante & 1,768 & $-5.3 e+03$ & $-1.6 \mathrm{e}+03$ & -278.293 & 9.949 & 127.104 & 722.119 & 496.376 & $\begin{array}{r}3,960.00 \\
0\end{array}$ & $1.3 \mathrm{e}+04$ & $1.9 \mathrm{e}+04$ & $\begin{array}{r}2,168.18 \\
9\end{array}$ \\
\hline FC (HR cash ex ante) & 1,768 & 0.000 & 0.000 & 0.000 & 0.000 & 0.000 & 0.201 & 0.000 & 1.000 & 1.000 & 1.000 & 0.401 \\
\hline HM measure & 986 & -0.201 & -0.201 & -0.154 & -0.072 & -0.012 & -0.012 & 0.048 & 0.130 & 0.219 & 0.219 & 0.086 \\
\hline FC(HM measure $)$ & 986 & 0.000 & 0.000 & 0.000 & 0.000 & 0.000 & 0.249 & 0.000 & 1.000 & 1.000 & 1.000 & 0.433 \\
\hline Equity beta & 1,828 & -0.198 & -0.053 & 0.344 & 0.853 & 1.182 & 1.194 & 1.539 & 2.066 & 2.474 & 2.535 & 0.516 \\
\hline BM at EoY 2019 & 1,848 & -1.147 & -0.886 & -0.036 & 0.150 & 0.316 & 0.462 & 0.636 & 1.526 & 3.017 & 3.247 & 0.573 \\
\hline $\ln (\mathrm{MVE})$ at EoY 2019 & 1,851 & 2.038 & 2.262 & 4.003 & 6.023 & 7.396 & 7.342 & 8.663 & 10.832 & 12.223 & 12.223 & 2.034 \\
\hline Momentum 2019 & 1,851 & -0.979 & -0.972 & -0.937 & -0.882 & -0.848 & -0.832 & -0.812 & -0.676 & -0.241 & -0.241 & 0.102 \\
\hline Profitability & 1,857 & -0.854 & -0.711 & -0.262 & 0.156 & 0.258 & 0.264 & 0.395 & 0.696 & 1.082 & 1.082 & 0.277 \\
\hline
\end{tabular}


Table 2

\section{Correlation matrix}

The table presents the correlation matrix for all dependent and independent variables we use. The sample consists of all nonfinancial and nonutility firms with available fiscal year 2019 data in Compustat. Appendix A shows the sample selection procedure. Appendix B defines all variables.

(1) Collapse period (CP) return
(2) Stimulus day (SD) return
(3) ROA (cumulative Q1 + Q2 2020)
(4) Assets (\$m)
(5) Cash / assets
(6) St debt / assets
(7) nSt debt / assets
(8) Lt debt / assets
(9) Book debt / assets
(10) Payout / assets
(11) Ind: 3-year cum. payouts / at
(12) Ind: COVID-19 conglomerate
(13) Ind: IG debt rating
(14) Ind: HY debt rating
(15) RD / assets
(16) SGA / sales
(17) Capex / lagged assets
(18) GOGS / sales
(19) FC (KZ index)
(20) FC (WW index)
(21) FC (SA index)
(22) FC (HR cash ex ante)
(23) FC (HM measure)
(24) Equity beta
(25) BM at EoY 2019
(26) ln(MVE) at EoY 2019
(27) Momentum 2019
(28) Profitability

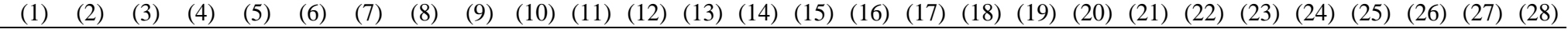
1

$\begin{array}{rr}-0.37 & 1 \\ 0.07 & 0.08\end{array}$

$\begin{array}{lll}0.07 & 0.08 \quad 1\end{array}$

$\begin{array}{llll}0.01 & 0.05 & 0.15 & 1\end{array}$

$0.2-0.09-0.58-0.18$

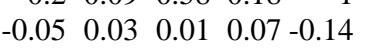

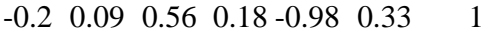

$\begin{array}{llllllll}-0.19 & 0.14 & 0.21 & 0.07 & -0.35 & 0.07 & 0.35 & 1\end{array}$

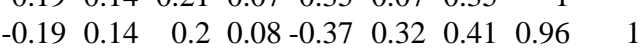

$\begin{array}{llllllllll}0.03 & 0.05 & 0.31 & 0.13 & -0.13 & 0.05 & 0.14 & 0.15 & 0.16 & 1\end{array}$

$\begin{array}{lllllllllll}0.04 & 0.03 & 0.24 & 0.15 & -0.08 & 0.03 & 0.08 & 0.06 & 0.07 & 0.68 & 1\end{array}$

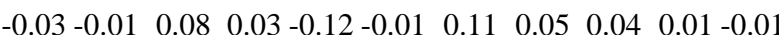

$\begin{array}{lllllllllllll}0.01 & 0.07 & 0.19 & 0.53 & -0.2 & 0.05 & 0.2 & 0.05 & 0.06 & 0.24 & 0.27 & 0.01\end{array}$

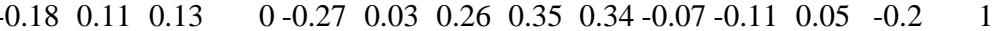

$\begin{array}{lllllllll}0.16-0.11-0.74-0.13 & 0.69-0.03-0.67-0.23-0.23-0.15 & -0.1 & -0.11-0.16-0.22 & 1\end{array}$

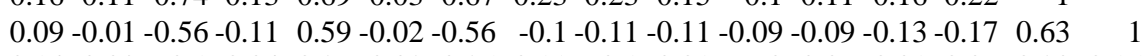

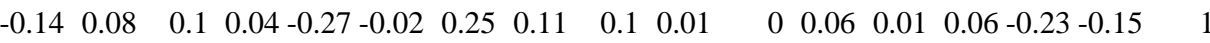

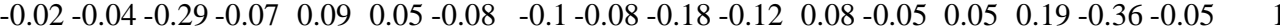

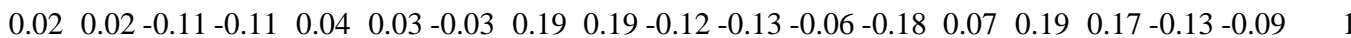

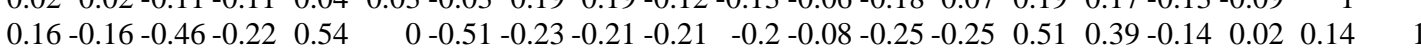

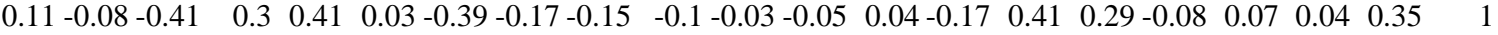

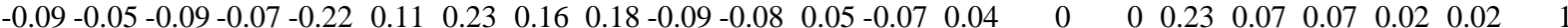

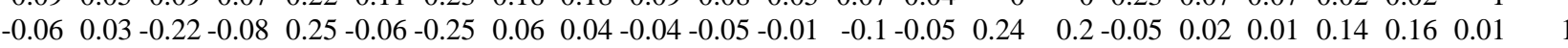

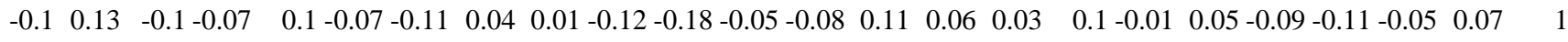

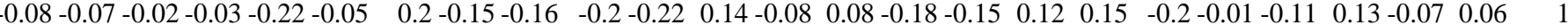

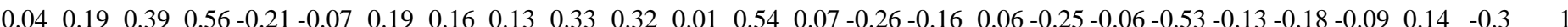

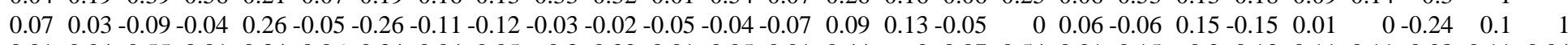

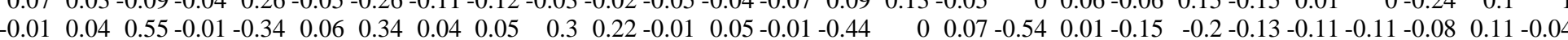

(28) Profitability 


\section{Table 3}

\section{Stock returns, financial flexibility measures, and stock and firm characteristics}

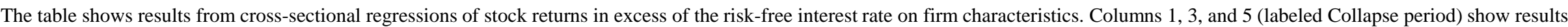

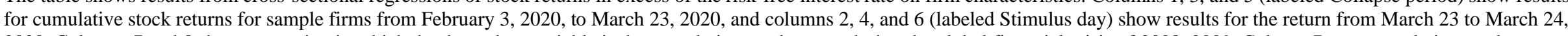

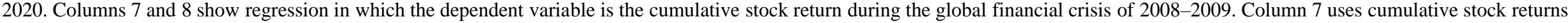

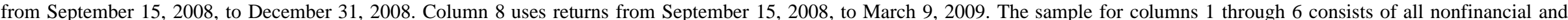

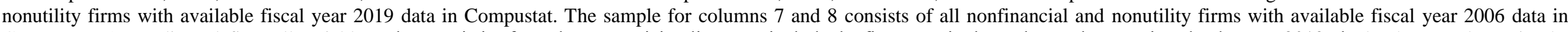

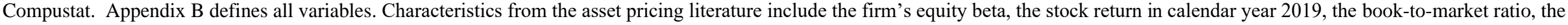

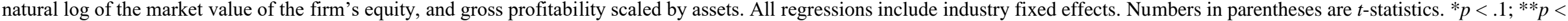
$.05 ; * * p<.01$

\begin{tabular}{|c|c|c|c|c|c|c|}
\hline & $\begin{array}{c}(1) \\
\text { Collapse period }\end{array}$ & $\begin{array}{c}(2) \\
\text { Stimulus day }\end{array}$ & $\begin{array}{c}(3) \\
\text { Collapse period }\end{array}$ & $\begin{array}{c}(4) \\
\text { Stimulus day }\end{array}$ & $\begin{array}{c}(5) \\
\text { Collapse period }\end{array}$ & $\begin{array}{c}\text { (6) } \\
\text { Stimulus day }\end{array}$ \\
\hline Cash / assets & $\begin{array}{c}0.134 * * * \\
(2.81)\end{array}$ & $\begin{array}{l}0.017 \\
(1.03)\end{array}$ & & & $\begin{array}{c}0.134 * * * \\
(2.82)\end{array}$ & $\begin{array}{l}0.017 \\
(1.03)\end{array}$ \\
\hline St debt / assets & $\begin{array}{c}-0.232 * * \\
(-2.03)\end{array}$ & $\begin{array}{l}0.051 \\
(1.29)\end{array}$ & & & & \\
\hline $\mathrm{nSt}$ debt / assets & & & $\begin{array}{c}-0.142 * * * \\
(-3.41)\end{array}$ & $\begin{array}{l}-0.009 \\
(-0.60)\end{array}$ & & \\
\hline Lt debt / assets & $\begin{array}{c}-0.163 * * * \\
(-5.28)\end{array}$ & $\begin{array}{c}0.025^{* *} \\
(2.32)\end{array}$ & $\begin{array}{c}-0.127 * * * \\
(-3.96)\end{array}$ & $\begin{array}{l}0.014 \\
(1.22)\end{array}$ & & \\
\hline Book debt / assets & & & & & $\begin{array}{c}-0.168 * * * \\
(-5.66)\end{array}$ & $\begin{array}{c}0.028 * * * \\
(2.70)\end{array}$ \\
\hline Ind: IG debt rating & $\begin{array}{l}-0.005 \\
(-0.28)\end{array}$ & $\begin{array}{l}-0.007 \\
(-1.01)\end{array}$ & $\begin{array}{l}-0.030 \\
(-1.51)\end{array}$ & $\begin{array}{l}0.001 \\
(0.12)\end{array}$ & $\begin{array}{l}-0.006 \\
(-0.33)\end{array}$ & $\begin{array}{l}-0.006 \\
(-0.96)\end{array}$ \\
\hline Ind: HY debt rating & & & $\begin{array}{c}-0.057 * * * \\
(-3.56)\end{array}$ & $\begin{array}{c}0.016 * * * \\
(2.93)\end{array}$ & & \\
\hline Capex / lagged assets & $\begin{array}{l}-0.071 \\
(-0.51)\end{array}$ & $\begin{array}{l}0.034 \\
(0.70)\end{array}$ & $\begin{array}{l}-0.095 \\
(-0.68)\end{array}$ & $\begin{array}{l}0.038 \\
(0.80)\end{array}$ & $\begin{array}{l}-0.073 \\
(-0.52)\end{array}$ & $\begin{array}{l}0.034 \\
(0.70)\end{array}$ \\
\hline SGA / sales & $\begin{array}{l}-0.027 * \\
(-1.76)\end{array}$ & $\begin{array}{c}0.011 * * \\
(2.09)\end{array}$ & $\begin{array}{l}-0.029 * \\
(-1.94)\end{array}$ & $\begin{array}{c}0.012 * * \\
(2.27)\end{array}$ & $\begin{array}{l}-0.027 * \\
(-1.77)\end{array}$ & $\begin{array}{c}0.011^{* *} \\
(2.08)\end{array}$ \\
\hline COGS / sales & $\begin{array}{c}0.067^{*} \\
(1.76)\end{array}$ & $\begin{array}{l}0.003 \\
(0.20)\end{array}$ & $\begin{array}{c}0.077 * * \\
(2.03)\end{array}$ & $\begin{array}{l}-0.000 \\
(-0.02)\end{array}$ & $\begin{array}{l}0.064^{*} \\
(1.68)\end{array}$ & $\begin{array}{l}0.004 \\
(0.29)\end{array}$ \\
\hline $\mathrm{RD} /$ assets & $\begin{array}{l}-0.008 \\
(-0.07)\end{array}$ & $\begin{array}{l}-0.002 \\
(-0.06)\end{array}$ & $\begin{array}{l}-0.025 \\
(-0.22)\end{array}$ & $\begin{array}{l}0.006 \\
(0.16)\end{array}$ & $\begin{array}{l}-0.014 \\
(-0.12)\end{array}$ & $\begin{array}{l}-0.000 \\
(-0.01)\end{array}$ \\
\hline Payout / assets & $\begin{array}{l}0.162 \\
(1.45)\end{array}$ & $\begin{array}{l}-0.026 \\
(-0.68)\end{array}$ & $\begin{array}{l}0.117 \\
(1.06)\end{array}$ & $\begin{array}{l}-0.009 \\
(-0.25)\end{array}$ & $\begin{array}{l}0.164 \\
(1.48)\end{array}$ & $\begin{array}{l}-0.026 \\
(-0.68)\end{array}$ \\
\hline Equity beta & $\begin{array}{c}-0.064 * * * \\
(-4.73)\end{array}$ & $\begin{array}{c}0.018 * * * \\
(3.98)\end{array}$ & $\begin{array}{c}-0.061 * * * \\
(-4.56)\end{array}$ & $\begin{array}{c}0.018 * * * \\
(3.87)\end{array}$ & $\begin{array}{c}-0.064 * * * \\
(-4.75)\end{array}$ & $\begin{array}{c}0.018 * * * \\
(3.96)\end{array}$ \\
\hline BM at EoY 2019 & $\begin{array}{l}0.024^{*} \\
(1.84)\end{array}$ & $\begin{array}{l}-0.007 \\
(-1.51)\end{array}$ & $\begin{array}{c}0.027 * * \\
(2.12)\end{array}$ & $\begin{array}{c}-0.008^{*} \\
(-1.86)\end{array}$ & $\begin{array}{l}0.023^{*} \\
(1.77)\end{array}$ & $\begin{array}{l}-0.006 \\
(-1.44)\end{array}$ \\
\hline $\ln (\mathrm{MVE})$ at EoY 2019 & $\begin{array}{c}0.013 * * * \\
(2.99)\end{array}$ & $\begin{array}{c}0.007 * * * * \\
(4.62)\end{array}$ & $\begin{array}{c}0.016 * * * \\
(3.75)\end{array}$ & $\begin{array}{c}0.006^{* * * *} \\
(3.85)\end{array}$ & $\begin{array}{c}0.013 * * * \\
(2.98)\end{array}$ & $\begin{array}{c}0.007 * * * \\
(4.62)\end{array}$ \\
\hline Momentum 2019 & $\begin{array}{l}-0.129 \\
(-1.25)\end{array}$ & $\begin{array}{c}0.090^{* *} \\
(2.54)\end{array}$ & $\begin{array}{l}-0.137 \\
(-1.34)\end{array}$ & $\begin{array}{c}0.093 * * * \\
(2.63)\end{array}$ & $\begin{array}{l}-0.131 \\
(-1.27)\end{array}$ & $\begin{array}{c}0.091 * * \\
(2.57)\end{array}$ \\
\hline Profitability & $\begin{array}{l}0.062 \\
(1.56) \\
\end{array}$ & $\begin{array}{l}0.003 \\
(0.21) \\
\end{array}$ & $\begin{array}{l}0.060 \\
(1.51) \\
\end{array}$ & $\begin{array}{r}0.003 \\
(0.19) \\
\end{array}$ & $\begin{array}{l}0.061 \\
(1.53) \\
\end{array}$ & $\begin{array}{l}0.003 \\
(0.23) \\
\end{array}$ \\
\hline $\begin{array}{l}\text { Observations } \\
\text { Adjusted } R^{2}\end{array}$ & $\begin{array}{l}1,489 \\
.197\end{array}$ & $\begin{array}{l}1,488 \\
.098\end{array}$ & $\begin{array}{l}1,489 \\
.203\end{array}$ & $\begin{array}{l}1,488 \\
.102\end{array}$ & $\begin{array}{l}1,489 \\
.198\end{array}$ & $\begin{array}{l}1,488 \\
.099\end{array}$ \\
\hline
\end{tabular}

\begin{tabular}{|c|c|}
\hline $\begin{array}{c}(7) \\
\text { Global financial crisis } \\
\text { ending Dec } 31,2008\end{array}$ & $\begin{array}{c}(8) \\
\text { Global financial crisis } \\
\text { ending March 9, } 2009\end{array}$ \\
\hline $\begin{array}{c}0.141 * * * \\
(3.60) \\
0.013 \\
(0.12)\end{array}$ & $\begin{array}{c}0.152 * * * \\
(3.43) \\
-0.035 \\
(-0.29)\end{array}$ \\
\hline $\begin{array}{c}-0.125^{* * * *} \\
(-3.36)\end{array}$ & $\begin{array}{c}-0.131 * * * \\
(-3.10)\end{array}$ \\
\hline $\begin{array}{c}0.054 * * \\
(2.55)\end{array}$ & $\begin{array}{c}0.057 * * \\
(2.39)\end{array}$ \\
\hline-0.042 & -0.011 \\
\hline $\begin{array}{c}(-0.54) \\
0.007\end{array}$ & $\begin{array}{c}(-0.13) \\
0.012\end{array}$ \\
\hline$(0.80)$ & (1.15) \\
\hline 0.008 & 0.023 \\
\hline$(0.21)$ & $(0.54)$ \\
\hline 0.034 & 0.036 \\
\hline$(0.30)$ & $(0.29)$ \\
\hline 0.108 & 0.099 \\
\hline (1.18) & $(0.96)$ \\
\hline $\begin{array}{c}-0.044 * * * \\
(-4.25)\end{array}$ & $\begin{array}{c}-0.029 * * \\
(-2.47)\end{array}$ \\
\hline$-0.061 * * *$ & $-0.075 * * *$ \\
\hline$(-2.63)$ & $(-2.86)$ \\
\hline 0.007 & 0.008 \\
\hline (1.51) & (1.46) \\
\hline-0.004 & 0.001 \\
\hline$(-0.31)$ & $(0.03)$ \\
\hline 0.032 & 0.029 \\
\hline$(0.90)$ & $(0.72)$ \\
\hline 1,691 & 1,689 \\
\hline .152 & .127 \\
\hline
\end{tabular}




\section{Table 4}

\section{Bottom-20 NAICS three-digit industries cumulative returns and industry characteristics: GFC versus COVID-19 crisis}

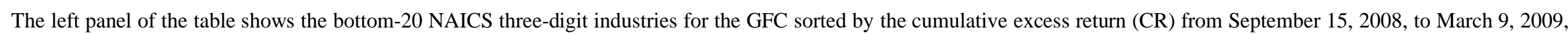

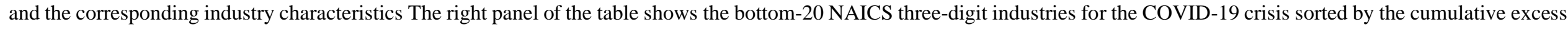

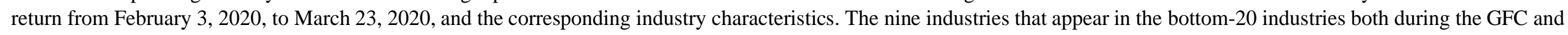
during the COVID-19 crisis are boldface.

\begin{tabular}{|c|c|c|c|c|c|}
\hline $\begin{array}{l}\text { NAICS } \\
\text { 3-digit } \\
\end{array}$ & NAICS 3-digit industry description & $\begin{array}{r}\text { Affected } \\
\text { share }\end{array}$ & $\begin{array}{l}\text { Lt debt } \\
\text { / assets }\end{array}$ & $\begin{array}{l}\text { PPE / } \\
\text { assets }\end{array}$ & $\mathrm{CR}$ \\
\hline \multicolumn{6}{|c|}{ Bottom-20 sorted on cumulative excess return } \\
\hline \multicolumn{6}{|c|}{ Global financial crisis } \\
\hline 314 & Textile product mills & 10 & 0.335 & 0.263 & -0.840 \\
\hline 485 & Transit and ground passenger transportation & 12 & 0.003 & 0.014 & -0.809 \\
\hline 313 & Textile mills & 9 & 0.182 & 0.205 & -0.719 \\
\hline 337 & Furniture and related product manufacturing & 9 & 0.219 & 0.253 & -0.693 \\
\hline 721 & Accommodation & 38 & 0.372 & 0.590 & -0.689 \\
\hline 213 & Support activities for mining & 31 & 0.205 & 0.518 & -0.682 \\
\hline 711 & $\begin{array}{l}\text { Performing arts, spectator sports, and related } \\
\text { industries }\end{array}$ & 27 & 0.250 & 0.649 & -0.677 \\
\hline 321 & Wood product manufacturing & 9 & 0.172 & 0.313 & -0.650 \\
\hline 238 & Specialty trade contractors & 16 & 0.216 & 0.195 & -0.650 \\
\hline 713 & Amusement, gambling, and recreation industries & 44 & 0.410 & 0.499 & -0.640 \\
\hline 211 & Oil and gas extraction & 17 & 0.250 & 0.722 & -0.637 \\
\hline 236 & Construction of buildings & 16 & 0.270 & 0.020 & -0.636 \\
\hline 327 & Nonmetallic mineral product manufacturing & 9 & 0.244 & 0.389 & -0.631 \\
\hline 336 & Transportation equipment manufacturing & 7 & 0.153 & 0.225 & -0.626 \\
\hline 331 & Primary metal manufacturing & 9 & 0.160 & 0.301 & -0.626 \\
\hline 488 & Support activities for transportation & 16 & 0.195 & 0.293 & -0.622 \\
\hline 333 & Machinery manufacturing & 9 & 0.134 & 0.163 & -0.617 \\
\hline 221 & Utilities & 20 & 0.177 & 0.457 & -0.614 \\
\hline 322 & Paper manufacturing & 10 & 0.261 & 0.432 & -0.611 \\
\hline \multirow[t]{3}{*}{315} & Apparel manufacturing & 10 & 0.133 & 0.135 & -0.609 \\
\hline & Mean & 16.4 & 0.217 & 0.332 & -0.664 \\
\hline & Median & 11.0 & 0.211 & 0.297 & -0.638 \\
\hline
\end{tabular}

\begin{tabular}{|c|c|c|c|c|c|}
\hline $\begin{array}{l}\text { NAICS } \\
\text { 3-digit } \\
\end{array}$ & NAICS 3-digit industry description & $\begin{array}{r}\text { Affected } \\
\text { share }\end{array}$ & $\begin{array}{r}\text { Lt debt / } \\
\text { assets } \\
\end{array}$ & $\begin{array}{l}\text { PPE / } \\
\text { assets }\end{array}$ & $\mathrm{CR}$ \\
\hline \multicolumn{6}{|c|}{ Bottom-20 sorted on cumulative excess return } \\
\hline \multicolumn{6}{|c|}{ COVID-19 crisis } \\
\hline 211 & Oil and gas extraction & 17 & 0.339 & 0.852 & -0.652 \\
\hline 213 & Support activities for mining & 31 & 0.279 & 0.534 & -0.650 \\
\hline 486 & Pipeline transportation & 10 & 0.599 & 0.606 & -0.616 \\
\hline 713 & $\begin{array}{l}\text { Amusement, gambling, and recreation } \\
\text { industries }\end{array}$ & 44 & 0.632 & 0.594 & -0.614 \\
\hline 442 & Furniture and home furnishings stores & 64 & 0.442 & 0.656 & -0.573 \\
\hline 236 & Construction of buildings & 16 & 0.361 & 0.028 & -0.564 \\
\hline 314 & Textile product mills & 10 & 0.337 & 0.348 & -0.554 \\
\hline 451 & $\begin{array}{l}\text { Sporting goods, hobby, musical instrument, and } \\
\text { bookstores }\end{array}$ & 82 & 0.529 & 0.549 & -0.550 \\
\hline 512 & Motion picture and sound recording industries & 43 & 0.458 & 0.694 & -0.538 \\
\hline 483 & Water transportation & 9 & 0.316 & 0.761 & -0.533 \\
\hline 481 & Air transportation & 48 & 0.345 & 0.733 & -0.532 \\
\hline 721 & Accommodation & 38 & 0.516 & 0.502 & -0.522 \\
\hline 324 & Petroleum and coal products manufacturing & 12 & 0.306 & 0.490 & -0.520 \\
\hline 448 & Clothing and clothing accessories stores & 90 & 0.417 & 0.555 & -0.514 \\
\hline 722 & Food services and drinking places & 53 & 0.566 & 0.565 & -0.513 \\
\hline 441 & Motor vehicle and parts dealers & 44 & 0.320 & 0.334 & -0.506 \\
\hline 313 & Textile mills & 9 & 0.251 & 0.339 & -0.500 \\
\hline 327 & Nonmetallic mineral product manufacturing & 9 & 0.380 & 0.337 & -0.494 \\
\hline 532 & Rental and leasing services & 39 & 0.484 & 0.670 & -0.490 \\
\hline \multirow[t]{3}{*}{337} & Furniture and related product manufacturing & 9 & 0.227 & 0.315 & -0.487 \\
\hline & Mean & 33.9 & 0.405 & 0.523 & -0.546 \\
\hline & Median & 34.5 & 0.371 & 0.552 & -0.532 \\
\hline
\end{tabular}




\section{Table 5}

\section{Stock returns, financial flexibility measures interacted with COVID-19 exposure measures, and stock and firm characteristics}

The table shows results from cross-sectional regressions of stock returns in excess of the risk-free interest rate on firm characteristics. All columns show results for cumulative stock returns for sample firms from February 3, 2020, to March 23, 2020. Controls include the firm's equity beta, the stock return in calendar year 2006, the book-to-market ratio, the natural log of the market value of the firm's equity, and gross profitability scaled by assets, Capex / lagged assets, SGA / sales, RD / assets, payout / assets, and an indicator variable for investment-grade-rated debt. The table shows results for all nonfinancial and nonutility firms with available fiscal year 2019 data in Compustat. All regressions include industry fixed effects. Numbers in parentheses are $t$-statistics. ${ }^{*} p<.1 ; * * p<.05 ; * * p<.01$.

\begin{tabular}{|c|c|c|c|c|c|c|c|c|c|c|c|}
\hline & $\begin{array}{c}(1) \\
\text { Affected } \\
\text { share (TQ) }\end{array}$ & $\begin{array}{c}\text { (2) } \\
\text { Teamwork } \\
\text { share (TQ) }\end{array}$ & $\begin{array}{c}\text { (3) } \\
\text { Customer } \\
\text { share (TQ) }\end{array}$ & $\begin{array}{c}\text { (4) } \\
\text { Presence } \\
\text { share (TQ) }\end{array}$ & $\begin{array}{c}5) \\
\text { Affected } \\
\text { share corrected } \\
\text { for Frésard, } \\
\text { Hoberg, and } \\
\text { Phillips (TQ) } \\
\end{array}$ & $\begin{array}{c}(6) \\
\text { Affected } \\
\text { share } \\
\text { corrected for } \\
\text { BEA USE } \\
\text { table (TQ) } \\
\end{array}$ & $\begin{array}{c}(7) \\
\text { Q2 2020 } \\
\text { year-on- } \\
\text { year } \\
\text { change in } \\
\text { sales (BQ) } \\
\end{array}$ & $\begin{array}{c}(8) \\
\text { Share of jobs } \\
\text { that can be } \\
\text { performed } \\
\text { from home } \\
\text { (BQ) }\end{array}$ & $\begin{array}{c}\text { (9) } \\
\text { Labor } \\
\text { intensity based } \\
\text { on number of } \\
\text { employees } \\
\text { (TQ) }\end{array}$ & $\begin{array}{c}\text { (10) } \\
\text { Manually } \\
\text { classified } \\
\text { as highly } \\
\text { affected }\end{array}$ & $\begin{array}{c}\text { (11) } \\
\text { Ind: } \\
\text { COVID-19 } \\
\text { industries }\end{array}$ \\
\hline Cash / assets $\times$ highly affected & $\begin{array}{c}0.315^{* *} \\
(2.02)\end{array}$ & $\begin{array}{l}0.144 \\
(1.56)\end{array}$ & $\begin{array}{c}0.252 * * * \\
(2.67)\end{array}$ & $\begin{array}{l}0.230 \\
(1.42)\end{array}$ & $\begin{array}{l}0.299^{*} \\
(1.95)\end{array}$ & $\begin{array}{l}0.243^{*} \\
(1.69)\end{array}$ & $\begin{array}{l}0.036 \\
(0.41)\end{array}$ & $\begin{array}{l}0.052 \\
(0.35)\end{array}$ & $\begin{array}{l}-0.083 \\
(-0.92)\end{array}$ & $\begin{array}{l}0.256^{*} \\
(1.70)\end{array}$ & $\begin{array}{l}0.094 \\
(0.76)\end{array}$ \\
\hline St debt / assets $\times$ highly affected & $\begin{array}{l}-0.144 \\
(-0.61)\end{array}$ & $\begin{array}{l}0.153 \\
(0.55)\end{array}$ & $\begin{array}{l}-0.083 \\
(-0.36)\end{array}$ & $\begin{array}{l}-0.138 \\
(-0.58)\end{array}$ & $\begin{array}{l}-0.134 \\
(-0.56)\end{array}$ & $\begin{array}{l}-0.182 \\
(-0.77)\end{array}$ & $\begin{array}{l}0.162 \\
(0.72)\end{array}$ & $\begin{array}{l}-0.283 \\
(-1.22)\end{array}$ & $\begin{array}{l}-0.119 \\
(-0.33)\end{array}$ & $\begin{array}{l}-0.045 \\
(-0.20)\end{array}$ & $\begin{array}{l}-0.062 \\
(-0.27)\end{array}$ \\
\hline Lt debt / assets $\times$ highly affected & $\begin{array}{l}0.108 \\
(1.65)\end{array}$ & $\begin{array}{l}-0.026 \\
(-0.41)\end{array}$ & $\begin{array}{l}0.093 \\
(1.53)\end{array}$ & $\begin{array}{l}0.010 \\
(0.13)\end{array}$ & $\begin{array}{l}0.112^{*} \\
(1.71)\end{array}$ & $\begin{array}{l}0.084 \\
(1.33)\end{array}$ & $\begin{array}{l}-0.035 \\
(-0.62)\end{array}$ & $\begin{array}{l}0.040 \\
(0.60)\end{array}$ & $\begin{array}{c}-0.151^{* *} \\
(-2.25)\end{array}$ & $\begin{array}{l}-0.017 \\
(-0.28)\end{array}$ & $\begin{array}{l}-0.032 \\
(-0.53)\end{array}$ \\
\hline Cash / assets & $\begin{array}{c}0.103^{* *} \\
(2.07)\end{array}$ & $\begin{array}{l}0.086 \\
(1.51)\end{array}$ & $\begin{array}{l}0.065 \\
(1.20)\end{array}$ & $\begin{array}{c}0.122^{* *} \\
(2.46)\end{array}$ & $\begin{array}{c}0.103 * * \\
(2.07)\end{array}$ & $\begin{array}{c}0.104 * * \\
(2.07)\end{array}$ & $\begin{array}{c}0.171^{* * *} \\
(3.93)\end{array}$ & $\begin{array}{c}0.131 * * * \\
(2.62)\end{array}$ & $\begin{array}{c}0.140 * * * \\
(2.59)\end{array}$ & $\begin{array}{l}0.096^{*} \\
(1.94)\end{array}$ & $\begin{array}{c}0.121^{* *} \\
(2.33)\end{array}$ \\
\hline St debt / assets & $\begin{array}{l}-0.175 \\
(-1.18)\end{array}$ & $\begin{array}{c}-0.289 * * \\
(-2.23)\end{array}$ & $\begin{array}{l}-0.211 \\
(-1.39)\end{array}$ & $\begin{array}{l}-0.203 \\
(-1.44)\end{array}$ & $\begin{array}{l}-0.181 \\
(-1.22)\end{array}$ & $\begin{array}{l}-0.167 \\
(-1.12)\end{array}$ & $\begin{array}{c}-0.297 * * \\
(-2.50)\end{array}$ & $\begin{array}{l}-0.121 \\
(-0.81)\end{array}$ & $\begin{array}{c}-0.260 * * \\
(-1.99)\end{array}$ & $\begin{array}{l}-0.178 \\
(-1.14)\end{array}$ & $\begin{array}{l}-0.198 \\
(-1.14)\end{array}$ \\
\hline Lt debt / assets & $\begin{array}{c}-0.185^{* * *} \\
(-5.34)\end{array}$ & $\begin{array}{c}-0.154 * * * \\
(-4.31)\end{array}$ & $\begin{array}{c}-0.189 * * * \\
(-5.26)\end{array}$ & $\begin{array}{c}-0.155^{* * * *} \\
(-4.58)\end{array}$ & $\begin{array}{c}-0.187 * * * \\
(-5.37)\end{array}$ & $\begin{array}{c}-0.181 * * * \\
(-5.17)\end{array}$ & $\begin{array}{c}-0.155^{* * *} \\
(-5.16)\end{array}$ & $\begin{array}{c}-0.170 * * * \\
(-4.92)\end{array}$ & $\begin{array}{c}-0.146 * * * \\
(-4.16)\end{array}$ & $\begin{array}{c}-0.161 * * * \\
(-4.57)\end{array}$ & $\begin{array}{c}-0.152 * * * \\
(-4.11)\end{array}$ \\
\hline Ind: Highly affected & $\begin{array}{c}-0.098 * * \\
(-2.39)\end{array}$ & $\begin{array}{c}-0.068^{*} \\
(-1.66)\end{array}$ & $\begin{array}{c}-0.112 * * * \\
(-2.91)\end{array}$ & $\begin{array}{l}0.034 \\
(0.85)\end{array}$ & $\begin{array}{c}-0.097 * * \\
(-2.44)\end{array}$ & $\begin{array}{c}-0.078^{* *} \\
(-2.09)\end{array}$ & $\begin{array}{c}-0.132 * * * \\
(-4.57)\end{array}$ & $\begin{array}{l}-0.004 \\
(-0.11)\end{array}$ & $\begin{array}{l}0.040 \\
(1.20)\end{array}$ & $\begin{array}{c}-0.135^{* * * *} \\
(-3.93)\end{array}$ & $\begin{array}{l}- \\
- \\
-\end{array}$ \\
\hline Controls & Yes & Yes & Yes & Yes & Yes & Yes & Yes & Yes & Yes & Yes & Yes \\
\hline $\begin{array}{l}\text { Observations } \\
\text { Adjusted } R^{2}\end{array}$ & $\begin{array}{l}1,473 \\
.198\end{array}$ & $\begin{array}{c}1,473 \\
.198\end{array}$ & $\begin{array}{c}1,473 \\
.200\end{array}$ & $\begin{array}{c}1,473 \\
.197\end{array}$ & $\begin{array}{c}1,473 \\
.198\end{array}$ & $\begin{array}{l}1,473 \\
.197\end{array}$ & $\begin{array}{c}1,348 \\
.309\end{array}$ & $\begin{array}{c}1,485 \\
.196\end{array}$ & $\begin{array}{c}1,381 \\
.204\end{array}$ & $\begin{array}{c}1,489 \\
.213\end{array}$ & $\begin{array}{c}1,489 \\
.196\end{array}$ \\
\hline
\end{tabular}




\section{Table 6}

\section{Accounting performance (cumulative Q1+Q2), financial flexibility measures interacted with affectedness, and firm characteristics}

The table shows results from cross-sectional regressions of the return on assets on firm characteristics. Return on assets is defined as the cumulative quarterly operating income before depreciation for the first two quarters of 2020 divided by the total assets at year-end 2019. Lagged return on assets is defined as the cumulative quarterly operating income before depreciation for the first two quarters of 2019 divided by the total assets at year-end 2018. The dependent variable is winsorized at the 1st and 99th percentile. All regressions include industry fixed effects. Numbers in parentheses are $t$-statistics. ${ }^{*} p<.1 ; * * p<.05 ; * * * p .01$.

\begin{tabular}{|c|c|c|}
\hline \multirow{2}{*}{ Cumulative (Q1 + Q2) ROA } & (1) & (2) \\
\hline & ROA & $\mathrm{ROA}$ \\
\hline Cash / assets $\times$ highly affected & $\begin{array}{c}0.138 * * * \\
(2.93)\end{array}$ & $\begin{array}{l}0.093 * * \\
(2.29)\end{array}$ \\
\hline St debt / assets $\times$ highly affected & $\begin{array}{l}0.073 \\
(1.06)\end{array}$ & $\begin{array}{l}0.089 \\
(1.46)\end{array}$ \\
\hline Lt debt / assets $\times$ highly affected & $\begin{array}{l}0.004 \\
(0.22)\end{array}$ & $\begin{array}{l}0.022 \\
(1.32)\end{array}$ \\
\hline Cash / assets & $\begin{array}{c}-0.053 * * * \\
(-4.59)\end{array}$ & $\begin{array}{c}-0.027 * * \\
(-2.17)\end{array}$ \\
\hline St debt / assets & $\begin{array}{l}-0.019 \\
(-0.48)\end{array}$ & $\begin{array}{l}-0.052 \\
(-1.32)\end{array}$ \\
\hline Lt debt / assets & $\begin{array}{l}0.010 \\
(1.13)\end{array}$ & $\begin{array}{l}-0.001 \\
(-0.11)\end{array}$ \\
\hline Ind: Highly affected & $\begin{array}{c}-0.043 * * * \\
(-3.59)\end{array}$ & $\begin{array}{c}-0.043 * * * \\
(-4.25)\end{array}$ \\
\hline Payout / assets & & $\begin{array}{l}0.094 * * * \\
(3.29)\end{array}$ \\
\hline Ind: IG debt rating & & $\begin{array}{l}-0.003 \\
(-0.66)\end{array}$ \\
\hline Capex / lagged assets & & $\begin{array}{c}-0.090 * * \\
(-2.56)\end{array}$ \\
\hline SGA / sales & & $\begin{array}{c}-0.024 * * * \\
(-5.74)\end{array}$ \\
\hline COGS / sales & & $\begin{array}{l}0.004 \\
(0.43)\end{array}$ \\
\hline $\mathrm{RD} /$ assets & & $\begin{array}{c}-0.062^{* *} \\
(-2.08)\end{array}$ \\
\hline Firm age & & $\begin{array}{l}-0.000 \\
(-0.20)\end{array}$ \\
\hline $\begin{array}{c}\text { Lagged ROA: Q1+Q2 } 2019 / \\
\text { assets EoFY18 }\end{array}$ & $\begin{array}{l}0.791 * * * \\
(42.14)\end{array}$ & $\begin{array}{c}0.607 * * * \\
(19.83)\end{array}$ \\
\hline Equity beta & & $\begin{array}{c}-0.011 * * * \\
(-3.05)\end{array}$ \\
\hline BM at EoY 2019 & $\begin{array}{c}-0.008 * * \\
(-2.27)\end{array}$ & $\begin{array}{c}-0.012 * * * \\
(-3.83)\end{array}$ \\
\hline $\ln (\mathrm{MVE})$ at EoY 2019 & $\begin{array}{l}0.002 * * \\
(2.25)\end{array}$ & $\begin{array}{l}0.001 \\
(1.26)\end{array}$ \\
\hline Momentum 2019 & & $\begin{array}{l}0.036 \\
(1.40) \\
\end{array}$ \\
\hline $\begin{array}{l}\text { Observations } \\
\text { Adjusted } R^{2} \\
\end{array}$ & $\begin{array}{l}1,638 \\
.750 \\
\end{array}$ & $\begin{array}{c}1,403 \\
.607 \\
\end{array}$ \\
\hline
\end{tabular}




\section{Table 7}

\section{Payout ratios by quartile and financial flexibility measures}

The table presents summary statistics for financial flexibility and payout ratios for the entire sample, as well as for sample splits by payout ratio quartiles. Columns 1 to 3 present numbers if we use the 2019 payout / assets ratio to split the sample into quartiles, and columns 4 to 6 present the numbers if we use the cumulative payouts from 2017 to 2019 divided by 2019 assets to split the sample into quartiles and to calculate the ratios. Columns 1 and 4 show the number of observations with complete data; columns 2 and 5 show medians; and columns 3 and 6 show means. The variable (cash + payout) / (assets + payout) shows what the cash over assets ratio of a company would have been if the company had retained all 2019 payouts (columns 2 and 3) or all cumulative payouts between 2017 and 2019 (columns 5 and 6). The variable (Lt debt - payout) / assets shows what the long-term debt / assets ratio of a company would have been had the firm used all 2019 payouts (columns 2 and 3) or all cumulative payouts between 2017 and 2019 (columns 5 and 6) to pay down its long-term debt. The sample consists of all nonfinancial and nonutility firms with available fiscal year 2019 data in Compustat. Appendix A shows the sample selection procedure. Appendix B defines all variables.

\begin{tabular}{|c|c|c|c|c|c|c|}
\hline & \multicolumn{3}{|c|}{2019 payouts / 2019 assets } & \multicolumn{3}{|c|}{$(2017+2018+2019$ payouts) / 2019 assets } \\
\hline & $\mathrm{N}$ & Median & Mean & $\mathrm{N}$ & Median & Mean \\
\hline \multicolumn{7}{|l|}{ All firms } \\
\hline$\overline{\text { Cash / assets }}$ & 1,857 & 0.112 & 0.224 & 1,679 & 0.101 & 0.199 \\
\hline$($ Cash + payout $) /($ assets + payout $)$ & 1,857 & 0.150 & 0.251 & 1,679 & 0.202 & 0.272 \\
\hline Lt debt / assets & 1,841 & 0.259 & 0.279 & 1,664 & 0.270 & 0.288 \\
\hline (Lt debt - payout) / assets & 1,841 & 0.222 & 0.244 & 1,664 & 0.164 & 0.174 \\
\hline Payout / assets & 1,857 & 0.011 & 0.035 & 1,679 & 0.052 & 0.114 \\
\hline \multicolumn{7}{|l|}{ Top quartile payout ratio } \\
\hline Cash / assets & 464 & 0.100 & 0.150 & 420 & 0.107 & 0.164 \\
\hline$($ Cash + payout $) /($ assets + payout $)$ & 464 & 0.180 & 0.233 & 420 & 0.321 & 0.362 \\
\hline Lt debt / assets & 461 & 0.280 & 0.316 & 418 & 0.277 & 0.313 \\
\hline (Lt debt - payout) / assets & 461 & 0.183 & 0.204 & 418 & -0.014 & -0.019 \\
\hline Payout / assets & 464 & 0.080 & 0.111 & 420 & 0.261 & 0.337 \\
\hline \multicolumn{7}{|l|}{ Bottom quartile payout ratio } \\
\hline Cash / assets & 465 & 0.420 & 0.436 & 420 & 0.233 & 0.350 \\
\hline$($ Cash + payout $) /($ assets + payout $)$ & 465 & 0.420 & 0.436 & 420 & 0.235 & 0.350 \\
\hline Lt debt / assets & 458 & 0.134 & 0.222 & 413 & 0.220 & 0.268 \\
\hline (Lt debt - payouts) / assets & 458 & 0.134 & 0.221 & 413 & 0.216 & 0.266 \\
\hline Payout / assets & 465 & 0.000 & 0.000 & 420 & 0.000 & 0.001 \\
\hline \multicolumn{7}{|l|}{ Middle quartiles payout ratios } \\
\hline Cash / assets & 928 & 0.076 & 0.156 & 839 & 0.073 & 0.141 \\
\hline$($ Cash + payout $) /($ assets + payout $)$ & 928 & 0.093 & 0.168 & 839 & 0.135 & 0.188 \\
\hline Lt debt / assets & 922 & 0.286 & 0.289 & 833 & 0.282 & 0.285 \\
\hline (Lt debt - payout) / assets & 922 & 0.269 & 0.275 & 833 & 0.217 & 0.226 \\
\hline Payout / assets & 928 & 0.011 & 0.014 & 839 & 0.052 & 0.059 \\
\hline
\end{tabular}




\section{Table 8}

\section{Stock returns, financial flexibility measures, and a top quartile payout ratio indicator variable}

The table shows results from cross-sectional regressions of stock returns in excess of the risk-free interest rate on firm characteristics, and an indicator variable equal to one if the cumulative payouts over 2017 to 2019 over 2019 assets were in the top quartile of the distribution, and zero otherwise. All odd-numbered columns (Collapse period) show results for cumulative stock returns for sample firms from February 3, 2020, to March 23, 2020, and all even-numbered columns (Stimulus day) show results for the return from March 23 to March 24, 2020. Appendix B defines all variables. All regressions include industry fixed effects. Numbers in parentheses are $t$-statistics. $* p<.1 ; * * p<.05 ; * * * p<.01$.

\begin{tabular}{|c|c|c|c|c|}
\hline & $\begin{array}{c}(1) \\
\text { Collapse } \\
\text { period }\end{array}$ & $\begin{array}{c}(2) \\
\text { Stimulus } \\
\text { day }\end{array}$ & $\begin{array}{c}\text { (3) } \\
\text { Collapse } \\
\text { period }\end{array}$ & $\begin{array}{c}\text { (4) } \\
\text { Stimulus } \\
\text { day }\end{array}$ \\
\hline $\begin{array}{l}\text { Ind: 3-year cum. } \\
\text { payout/ }\end{array}$ & 0.018 & -0.002 & 0.016 & -0.003 \\
\hline assets top quartile & $(1.28)$ & $(-0.38)$ & (1.07) & $(-0.66)$ \\
\hline Cash / assets & & & $\begin{array}{l}0.155 * * * \\
\quad(3.25)\end{array}$ & $\begin{array}{l}0.023 \\
(1.33)\end{array}$ \\
\hline St debt / assets & & & $\begin{array}{c}-0.215^{*} \\
(-1.93)\end{array}$ & $\begin{array}{l}0.051 \\
(1.29)\end{array}$ \\
\hline Lt debt / assets & & & $\begin{array}{c}-0.147 * * * \\
(-4.82)\end{array}$ & $\begin{array}{c}0.023 * * \\
(2.10)\end{array}$ \\
\hline Ind: IG debt rating & & & $\begin{array}{l}-0.011 \\
(-0.61)\end{array}$ & $\begin{array}{l}-0.007 \\
(-0.99)\end{array}$ \\
\hline Capex / lagged assets & & & $\begin{array}{l}-0.082 \\
(-0.59)\end{array}$ & $\begin{array}{l}0.033 \\
(0.66)\end{array}$ \\
\hline SGA / sales & & & $\begin{array}{c}-0.041 * * \\
(-2.57)\end{array}$ & $\begin{array}{l}0.011^{*} \\
(1.87)\end{array}$ \\
\hline COGS / sales & & & $\begin{array}{c}0.082 * * \\
(2.17)\end{array}$ & $\begin{array}{l}0.006 \\
(0.45)\end{array}$ \\
\hline $\mathrm{RD} /$ assets & & & $\begin{array}{l}0.104 \\
(0.87)\end{array}$ & $\begin{array}{l}0.005 \\
(0.11)\end{array}$ \\
\hline Equity beta & $\begin{array}{c}-0.056^{* * * *} \\
(-4.73)\end{array}$ & $\begin{array}{l}0.022 * * * \\
(5.51)\end{array}$ & $\begin{array}{c}-0.072 * * * \\
(-5.39)\end{array}$ & $\begin{array}{l}0.019 * * * \\
(3.99)\end{array}$ \\
\hline BM at EoY 2019 & $\begin{array}{c}0.035^{* * *} \\
(3.19)\end{array}$ & $\begin{array}{c}- \\
0.011^{* * *} \\
(-2.82)\end{array}$ & $0.030 * *$ & $\begin{array}{l}-0.007 \\
(-1.47)\end{array}$ \\
\hline $\ln (\mathrm{MVE})$ at EoY 2019 & $\begin{array}{c}0.013 * * * \\
(4.16)\end{array}$ & $\begin{array}{c}0.005 * * * \\
(4.36)\end{array}$ & $\begin{array}{c}0.016 * * * \\
(3.72)\end{array}$ & $\begin{array}{c}0.007 * * * \\
(4.72)\end{array}$ \\
\hline Momentum 2019 & $\begin{array}{l}-0.073 \\
(-0.91)\end{array}$ & $\begin{array}{c}0.079 * * * \\
(2.90)\end{array}$ & $\begin{array}{l}-0.148 \\
(-1.37)\end{array}$ & $\begin{array}{c}0.091 * * \\
(2.37)\end{array}$ \\
\hline Profitability & $\begin{array}{l}0.038 \\
(1.62)\end{array}$ & $\begin{array}{l}-0.001 \\
(-0.14)\end{array}$ & $\begin{array}{c}0.078^{* *} \\
(2.04) \\
\end{array}$ & $\begin{array}{l}0.004 \\
(0.26)\end{array}$ \\
\hline Observations & 1,671 & 1,670 & 1,423 & 1,422 \\
\hline Adjusted $R^{2}$ & .154 & .097 & .213 & .105 \\
\hline
\end{tabular}


Table 9

\section{Stock returns, financial flexibility measures, and conglomerate indicator variables}

The table shows results from cross-sectional regressions of stock returns in excess of the risk-free interest rate on firm characteristics and a COVID-19 conglomerate indicator variable equal to one if the firm reports sales in two or more different NAICS three-digit industries in the Compustat Segments database, and if the firm operates at least one (but not all) segment(s) in a highly affected NAICS three-digit industry (defined as being in the top quartile of Koren and Peto's [2020] affected share measure), and zero otherwise. All odd-numbered columns (Collapse period) show results for cumulative stock returns for sample firms from February 3, 2020, to March 23, 2020, and all even-numbered columns (Stimulus day) show results for the return from March 23 to March 24, 2020. Appendix B defines all variables. Numbers in parentheses are $t$-statistics. * $p<.1 ; * * p<.05 ; * * * p$ $<.01$.

${ }^{\text {a}}$ Testing whether or not the coefficient for Ind: COVID-19 conglomerate is significantly smaller than Ind: Highly affected (set to zero for COVID-19 conglomerate) based on a one-sided Wald test cannot be rejected at the $10 \%$ level in column $1(p=.125)$, column $3(p=.230)$, and column $4(p=.198)$, but is rejected at the $5 \%$ level in column $2(p=.041)$.

\begin{tabular}{|c|c|c|c|c|}
\hline & $\begin{array}{c}(1) \\
\text { Collapse } \\
\text { period }\end{array}$ & $\begin{array}{c}(2) \\
\text { Stimulus } \\
\text { day }\end{array}$ & $\begin{array}{c}(3) \\
\text { Collapse } \\
\text { period }\end{array}$ & $\begin{array}{c}(4) \\
\text { Stimulus } \\
\text { day }\end{array}$ \\
\hline Cash / assets $\times$ & & & 0.170 & -0.024 \\
\hline Ind: COVID-19 conglomerate & & & $(0.64)$ & $(-0.27)$ \\
\hline St debt / assets $\times$ & & & 0.263 & 0.034 \\
\hline Ind: COVID-19 conglomerate & & & $(0.54)$ & $(0.21)$ \\
\hline Lt debt / assets $\times$ & & & 0.129 & 0.063 \\
\hline Ind: COVID-19 conglomerate & & & $(0.99)$ & $(1.43)$ \\
\hline Cash / assets $\times$ Ind: Highly affected & & & $0.296^{*}$ & $\begin{array}{l}0.043 \\
(075)\end{array}$ \\
\hline $\begin{array}{l}\text { St debt / assets } \times \text { Ind: Highly affected } \\
\quad \text { (set to zero for COVID-19 conglomerate) }\end{array}$ & & & $\begin{array}{l}0.321 \\
(1.32)\end{array}$ & $\begin{array}{c}-0.159^{*} \\
(-1.95)\end{array}$ \\
\hline $\begin{array}{l}\text { Lt debt / assets } \times \text { Ind: Highly affected } \\
\quad(\text { set to zero for COVID-19 conglomerate) }\end{array}$ & & & $\begin{array}{l}0.120^{*} \\
(1.80)\end{array}$ & $\begin{array}{c}0.052 * * \\
(2.33)\end{array}$ \\
\hline Cash / assets & $\begin{array}{c}0.191 * * * \\
(3.98)\end{array}$ & $\begin{array}{l}0.011 \\
(0.66)\end{array}$ & $\begin{array}{c}0.156^{* * *} \\
(3.08)\end{array}$ & $\begin{array}{l}0.008 \\
(0.48)\end{array}$ \\
\hline St debt / assets & $\begin{array}{l}-0.086 \\
(-0.75)\end{array}$ & $\begin{array}{l}0.025 \\
(0.65)\end{array}$ & $\begin{array}{l}-0.209 \\
(-1.37)\end{array}$ & $\begin{array}{r}0.087^{*} \\
(1.69)\end{array}$ \\
\hline Lt debt / assets & $\begin{array}{c}-0.163 * * * \\
(-5.34)\end{array}$ & $\begin{array}{l}0.033 * * * \\
(3.25)\end{array}$ & $\begin{array}{c}-0.195 * * * \\
(-5.57)\end{array}$ & $\begin{array}{l}0.017 \\
(1.46)\end{array}$ \\
\hline Ind: COVID-19 conglomerate & $\begin{array}{c}-0.026 a) \\
(-1.07)\end{array}$ & $\begin{array}{c}0.001 \mathrm{a}) \\
(0.13)\end{array}$ & $\begin{array}{l}-0.091^{\mathrm{a}} \\
(-1.51)\end{array}$ & $\begin{array}{l}-0.018^{\mathrm{a}} \\
(-0.91)\end{array}$ \\
\hline Ind: Highly affected (set to zero & $0.058^{\mathrm{a}, * * *}$ & $\begin{array}{l}0.017 \\
\mathrm{a}, * * *\end{array}$ & $\begin{array}{l}-0.140 \\
\mathrm{a}, * * *\end{array}$ & $0.001^{\mathrm{a}}$ \\
\hline for COVID-19 conglomerate) & $(-3.31)$ & $(2.88)$ & $(-3.80)$ & $(0.05)$ \\
\hline Ind: IG debt rating & $\begin{array}{l}-0.012 \\
(-0.60)\end{array}$ & $\begin{array}{l}-0.008 \\
(-1.29)\end{array}$ & $\begin{array}{l}-0.009 \\
(-0.46)\end{array}$ & $\begin{array}{l}-0.009 \\
(-1.34)\end{array}$ \\
\hline Capex / lagged assets & $\begin{array}{c}-0.344 * * \\
(-2.52)\end{array}$ & $\begin{array}{l}0.052 \\
(1.13)\end{array}$ & $\begin{array}{c}-0.327 * * \\
(-2.39)\end{array}$ & $\begin{array}{l}0.049 \\
(1.07)\end{array}$ \\
\hline SGA / sales & $\begin{array}{l}-0.003 \\
(-0.20)\end{array}$ & $\begin{array}{l}0.006 \\
(1.21)\end{array}$ & $\begin{array}{l}-0.002 \\
(-0.11)\end{array}$ & $\begin{array}{l}0.007 \\
(1.41)\end{array}$ \\
\hline COGS / sales & $\begin{array}{l}0.004 \\
(0.13)\end{array}$ & $\begin{array}{c}0.024 * * \\
(2.14)\end{array}$ & $\begin{array}{l}-0.007 \\
(-0.22)\end{array}$ & $\begin{array}{c}0.026^{* * *} \\
(2.29)\end{array}$ \\
\hline $\mathrm{RD} /$ assets & $\begin{array}{l}0.059 \\
(0.52)\end{array}$ & $\begin{array}{l}-0.014 \\
(-0.38)\end{array}$ & $\begin{array}{l}0.080 \\
(0.69)\end{array}$ & $\begin{array}{l}-0.019 \\
(-0.49)\end{array}$ \\
\hline Payout / assets & $\begin{array}{l}-0.019 \\
(-0.17)\end{array}$ & $\begin{array}{l}-0.003 \\
(-0.08)\end{array}$ & $\begin{array}{l}-0.011 \\
(-0.10)\end{array}$ & $\begin{array}{l}-0.011 \\
(-0.30)\end{array}$ \\
\hline Equity beta & $\begin{array}{c}-0.080 * * * \\
(-6.37)\end{array}$ & $\begin{array}{c}0.016 * * * \\
(3.89)\end{array}$ & $\begin{array}{c}-0.078 * * * \\
(-6.21)\end{array}$ & $\begin{array}{c}0.018 * * * \\
(4.18)\end{array}$ \\
\hline BM at EoY 2019 & $\begin{array}{l}0.020 \\
(1.57)\end{array}$ & $\begin{array}{l}-0.007 \\
(-1.53)\end{array}$ & $\begin{array}{l}0.024 * \\
(1.85)\end{array}$ & $\begin{array}{l}-0.007 \\
(-1.47)\end{array}$ \\
\hline $\ln (\mathrm{MVE})$ at EoY 2019 & $\begin{array}{c}0.018 * * * \\
(4.02)\end{array}$ & $\begin{array}{c}0.006^{* * * *} \\
(4.30)\end{array}$ & $\begin{array}{c}0.017 * * * \\
(3.93)\end{array}$ & $\begin{array}{c}0.006^{* * * *} \\
(4.38)\end{array}$ \\
\hline Momentum 2019 & $\begin{array}{l}-0.142 \\
(-1.36)\end{array}$ & $\begin{array}{c}0.118 * * * \\
(3.36)\end{array}$ & $\begin{array}{l}-0.137 \\
(-1.31)\end{array}$ & $\begin{array}{c}0.122 * * * \\
(3.47)\end{array}$ \\
\hline Profitability & $\begin{array}{c}0.136 * * * \\
(3.82)\end{array}$ & $\begin{array}{l}-0.006 \\
(-0.46)\end{array}$ & $\begin{array}{c}0.127 * * * \\
(3.52)\end{array}$ & $\begin{array}{l}-0.006 \\
(-0.46)\end{array}$ \\
\hline Industry fixed effects & No & No & No & No \\
\hline Observations & $55^{1,474}$ & 1,473 & 1,474 & 1,473 \\
\hline
\end{tabular}


Table 10

\section{Stock returns and measures of financial constraints}

The table shows results from cross-sectional regressions of stock returns in excess of the risk-free interest rate on measures of financial constraints. All oddnumbered columns (Collapse period) show results for cumulative stock returns for sample firms from February 3, 2020, to March 23, 2020, and all even-numbered columns (Stimulus day) show results for the return from March 23 to March 24, 2020. Appendix B defines all variables. Characteristics from the asset pricing literature include the firm's equity beta, the stock return in calendar year 2019, the book-to-market ratio, the natural log of the market value of the firm's equity, and gross profitability scaled by assets. All regressions include industry fixed effects. Numbers in parentheses are $t$-statistics. ${ }^{*} p<.1 ; * * p<.05 ; * * * p<.01$.

\begin{tabular}{|c|c|c|c|c|c|c|c|c|c|c|}
\hline & $\begin{array}{c}\text { (1) } \\
\text { Collapse } \\
\text { period } \\
\end{array}$ & $\begin{array}{c}(2) \\
\text { Stimulus } \\
\text { day }\end{array}$ & $\begin{array}{c}(3) \\
\text { Collapse } \\
\text { period }\end{array}$ & $\begin{array}{c}(4) \\
\text { Stimulus } \\
\text { day }\end{array}$ & $\begin{array}{c}\text { (5) } \\
\text { Collapse } \\
\text { period } \\
\end{array}$ & $\begin{array}{c}(6) \\
\text { Stimulus } \\
\text { day }\end{array}$ & $\begin{array}{c}(7) \\
\text { Collapse } \\
\text { period } \\
\end{array}$ & $\begin{array}{c}(8) \\
\text { Stimulus } \\
\text { day }\end{array}$ & $\begin{array}{c}(9) \\
\text { Collapse } \\
\text { period } \\
\end{array}$ & $\begin{array}{c}(10) \\
\text { Stimulus } \\
\text { day }\end{array}$ \\
\hline FC (WW index) & $\begin{array}{c}0.045^{* *} \\
(2.26)\end{array}$ & $\begin{array}{l}0.001 \\
(0.09)\end{array}$ & & & & & & & & \\
\hline $\mathrm{FC}(\mathrm{KZ}$ index $)$ & & & $\begin{array}{l}-0.016 \\
(-1.12)\end{array}$ & $\begin{array}{l}0.006 \\
(1.28)\end{array}$ & & & & & & \\
\hline FC (SA index) & & & & & $\begin{array}{l}0.011 \\
(0.78)\end{array}$ & $\begin{array}{l}0.003 \\
(0.56)\end{array}$ & & & & \\
\hline FC (HM measure) & & & & & & & $\begin{array}{c}-0.045 * * * \\
(-2.73)\end{array}$ & $\begin{array}{c}0.012 * * \\
(2.25)\end{array}$ & & \\
\hline FC (HR cash ex ante) & & & & & & & & & $\begin{array}{c}-0.035^{* *} \\
(-2.43)\end{array}$ & $\begin{array}{l}-0.003 \\
(-0.66)\end{array}$ \\
\hline Equity beta & $\begin{array}{c}-0.055 * * * \\
(-4.51)\end{array}$ & $\begin{array}{c}0.024 * * * \\
(5.75)\end{array}$ & $\begin{array}{c}-0.049 * * * \\
(-3.85)\end{array}$ & $\begin{array}{c}0.021 * * * \\
(5.07)\end{array}$ & $\begin{array}{c}-0.045 * * * \\
(-3.86)\end{array}$ & $\begin{array}{c}0.021 * * * \\
(5.67)\end{array}$ & $\begin{array}{c}-0.069 * * * \\
(-4.69)\end{array}$ & $\begin{array}{c}0.021 * * * \\
(4.34)\end{array}$ & $\begin{array}{c}-0.051 * * * \\
(-4.35)\end{array}$ & $\begin{array}{c}0.022 * * * \\
(5.68)\end{array}$ \\
\hline BM at EoY 2019 & $\begin{array}{c}0.035^{* * * *} \\
(3.12)\end{array}$ & $\begin{array}{c}-0.011 * * * \\
(-2.86)\end{array}$ & $\begin{array}{c}0.033 * * * \\
(2.63)\end{array}$ & $\begin{array}{c}-0.010 * * \\
(-2.45)\end{array}$ & $\begin{array}{c}0.032 * * * \\
(2.87)\end{array}$ & $\begin{array}{c}-0.010 * * * \\
(-2.70)\end{array}$ & $\begin{array}{c}0.037 * * * \\
(2.61)\end{array}$ & $\begin{array}{l}-0.007 \\
(-1.40)\end{array}$ & $\begin{array}{c}0.033 * * * \\
(3.00)\end{array}$ & $\begin{array}{c}-0.011 * * * \\
(-2.97)\end{array}$ \\
\hline $\ln (\mathrm{MVE})$ at EoY 2019 & $\begin{array}{c}0.017 * * * \\
(4.64)\end{array}$ & $\begin{array}{c}0.005 * * * \\
(3.76)\end{array}$ & $\begin{array}{c}0.011 * * * \\
(3.34)\end{array}$ & $\begin{array}{c}0.005 * * * \\
(4.54)\end{array}$ & $\begin{array}{c}0.013 * * * \\
(4.39)\end{array}$ & $\begin{array}{c}0.005^{* * * *} \\
(5.02)\end{array}$ & $\begin{array}{c}0.013 * * * \\
(3.47)\end{array}$ & $\begin{array}{c}0.006^{* * * *} \\
(4.64)\end{array}$ & $\begin{array}{c}0.012 * * * \\
(3.91)\end{array}$ & $\begin{array}{c}0.004 * * * \\
(4.42)\end{array}$ \\
\hline Momentum 2019 & $\begin{array}{l}-0.065 \\
(-0.69)\end{array}$ & $\begin{array}{c}0.065^{* *} \\
(2.06)\end{array}$ & $\begin{array}{l}-0.073 \\
(-0.79)\end{array}$ & $\begin{array}{c}0.084 * * * \\
(2.82)\end{array}$ & $\begin{array}{l}-0.011 \\
(-0.15)\end{array}$ & $\begin{array}{c}0.048^{* *} \\
(2.10)\end{array}$ & $\begin{array}{l}-0.016 \\
(-0.18)\end{array}$ & $\begin{array}{c}0.075^{* *} \\
(2.52)\end{array}$ & $\begin{array}{l}-0.037 \\
(-0.48)\end{array}$ & $\begin{array}{c}0.061 * * \\
(2.42)\end{array}$ \\
\hline Profitability & $\begin{array}{l}0.033 \\
(1.34)\end{array}$ & $\begin{array}{l}-0.001 \\
(-0.18)\end{array}$ & $\begin{array}{l}0.034 \\
(1.34)\end{array}$ & $\begin{array}{l}-0.002 \\
(-0.19)\end{array}$ & $\begin{array}{c}0.050^{* *} \\
(2.12)\end{array}$ & $\begin{array}{l}-0.003 \\
(-0.34)\end{array}$ & $\begin{array}{l}0.033 \\
(1.12)\end{array}$ & $\begin{array}{l}-0.003 \\
(-0.31)\end{array}$ & $\begin{array}{l}0.037 \\
(1.55)\end{array}$ & $\begin{array}{l}-0.003 \\
(-0.36)\end{array}$ \\
\hline $\begin{array}{l}\text { Observations } \\
\text { Adjusted } R^{2}\end{array}$ & $\begin{array}{l}1,650 \\
.158\end{array}$ & $\begin{array}{c}1,649 \\
.092\end{array}$ & $\begin{array}{l}1,566 \\
.142\end{array}$ & $\begin{array}{c}1,566 \\
.097\end{array}$ & $\begin{array}{l}1,820 \\
.142\end{array}$ & $\begin{array}{c}1,819 \\
.094\end{array}$ & $\begin{array}{l}980 \\
.150 \\
\end{array}$ & $\begin{array}{l}979 \\
.128 \\
\end{array}$ & $\begin{array}{c}1,761 \\
.146\end{array}$ & $\begin{array}{l}1,760 \\
.093\end{array}$ \\
\hline
\end{tabular}




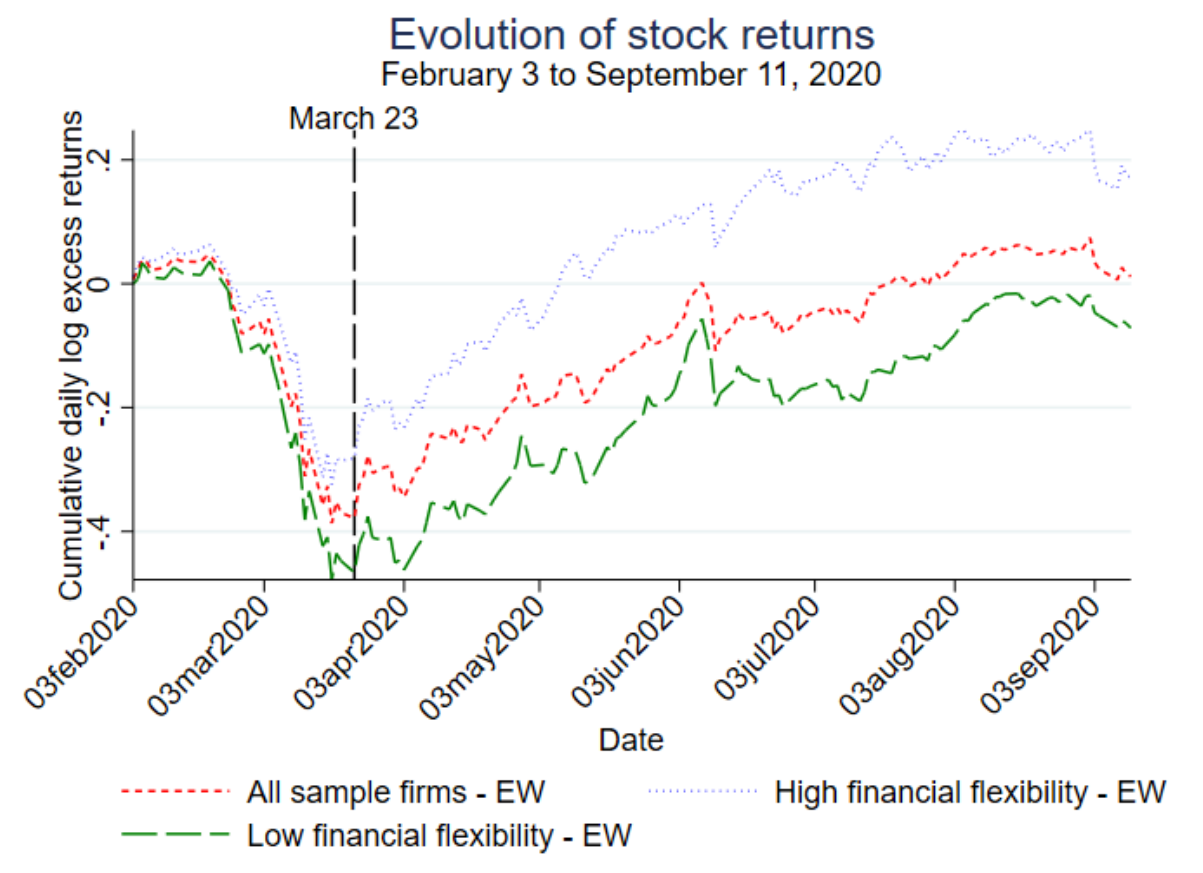

\section{Figure 1}

Evolution of stock returns for groups of firms with high and low financial flexibility

The figure shows cumulative daily log excess stock returns from February 3 to September 11, 2020, for three different portfolios. The red-dashed line represents returns for an equal-weighted portfolio of all sample firms. The blue-dotted line represents returns for a portfolio of 257 sample firms with high financial flexibility, and the green-dashed line represents returns for a portfolio of 184 sample firms with low financial flexibility. We classify a firm as having high financial flexibility if it is in the top quartile of the cash over assets distribution and the bottom quartile of the long-term debt over assets distribution at the end of fiscal year 2019. A firm has low financial flexibility if it is in the bottom quartile of the cash over assets distribution and the top quartile of the long-term debt over assets distribution at the end of fiscal year 2019. 


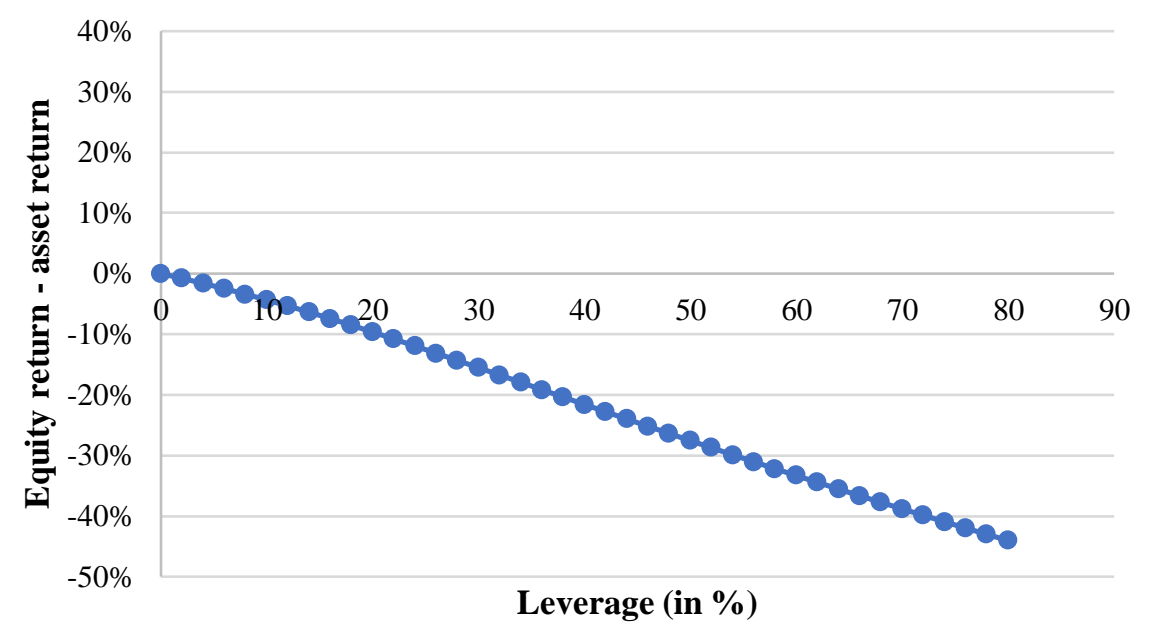

(A) Merton model calibration with constant asset volatility

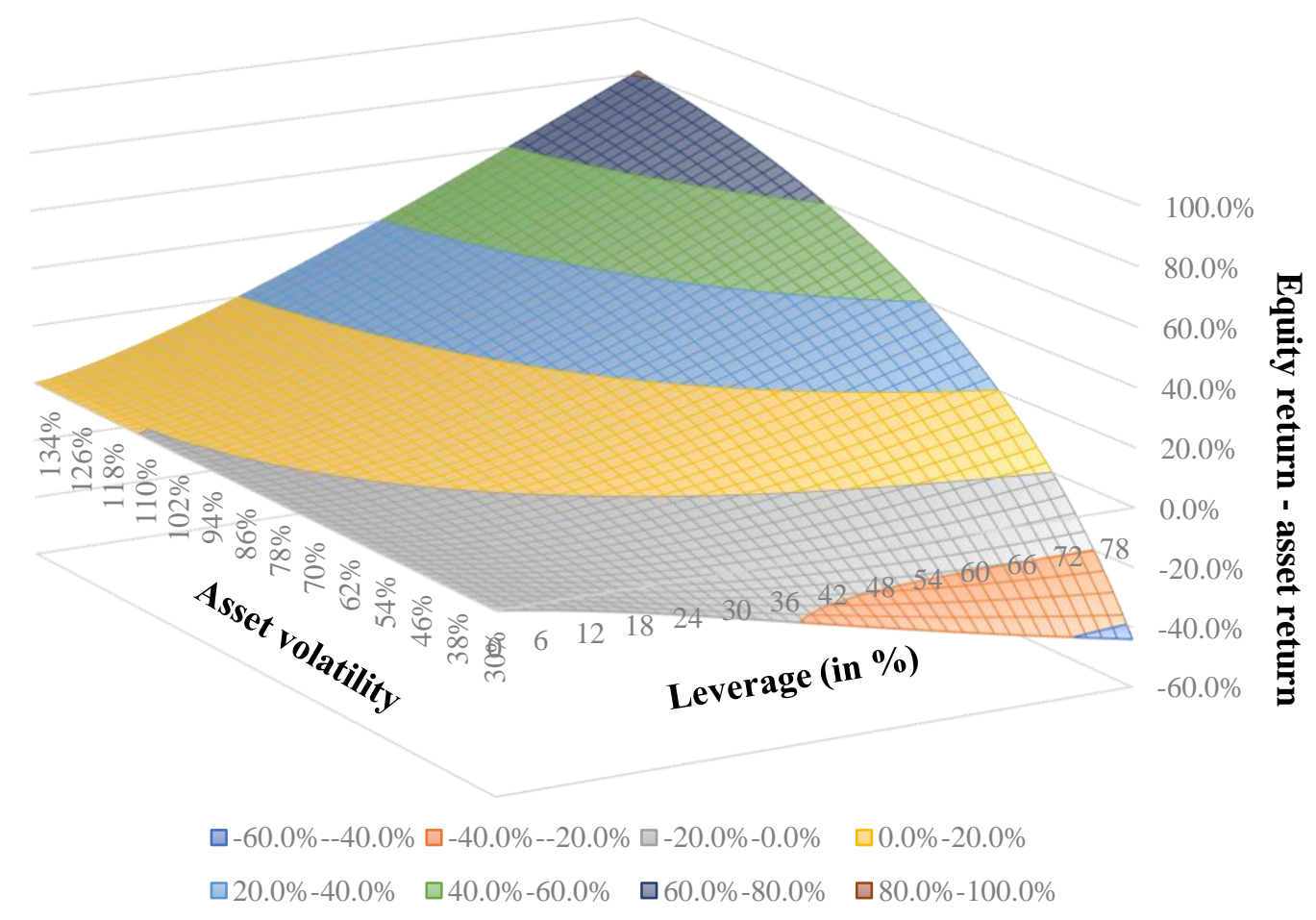

(B) Merton model calibration with varying asset volatility

\section{Figure 2}

\section{Calibration of the Merton model}

Panel A shows the difference in equity returns and asset returns for a large shock to asset returns as a function of leverage (the face value of debt) in a calibration of the Merton (1974) model. The initial values are $V_{0}=100 ; V_{\text {Shock }}=70.00, \sigma_{\text {assets }}=30 \%, r=3 \% ; q=1 \%, T=5$ years. Panel B shows the difference in equity returns and asset returns for a large shock to asset returns as a function of both leverage and asset volatility. 